\title{
BIOMATERIALS FOR INTERVERTEBRAL DISC REGENERATION: PAST PERFORMANCE AND POSSIBLE FUTURE STRATEGIES
}

\author{
E.M. Schutgens ${ }^{1}$, M.A. Tryfonidou ${ }^{2}$, T.H. Smit ${ }^{3}$, F. Cumhur Öner ${ }^{1}$, A. Krouwels ${ }^{1}$, K. Ito ${ }^{1,4}$ and L.B. Creemers ${ }^{1, *}$ \\ ${ }^{1}$ Department of Orthopaedics, University Medical Centre Utrecht, The Netherlands \\ ${ }^{2}$ Department of Clinical Sciences of Companion Animals, Faculty of Veterinary Medicine, Utrecht University, \\ The Netherlands \\ ${ }^{3}$ Department of Orthopaedics, VU University Medical Centre, Amsterdam, The Netherlands \\ ${ }^{4}$ Orthopaedic Biomechanics, Department of Biomedical Engineering, Eindhoven University of Technology, \\ The Netherlands
}

\begin{abstract}
Intervertebral disc (IVD) degeneration is associated with most cases of cervical and lumbar spine pathologies, amongst which chronic low back pain has become the number one cause of loss of quality-adjusted life years. In search of alternatives to the current less than optimal and usually highly invasive treatments, regenerative strategies are being devised, none of which has reached clinical practice as yet. Strategies include the use of stem cells, gene therapy, growth factors and biomaterial carriers. Biomaterial carriers are an important component in musculoskeletal regenerative medicine techniques. Several biomaterials, both from natural and synthetic origin, have been used for regeneration of the IVD in vitro and in vivo. Aspects such as ease of use, mechanical properties, regenerative capacity, and their applicability as carriers for regenerative and anti-degenerative factors determine their suitability for IVD regeneration. The current review provides an overview of the biomaterials used with respect to these properties, including their drawbacks. In addition, as biomaterial application until now appears to have been based on a mix of mere availability and intuition, a more rational design is proposed for future use of biomaterials for IVD regeneration. Ideally, high-throughput screening is used to identify optimally effective materials, or alternatively medium content comparative studies should be carried out to determine an appropriate reference material for future studies on novel materials.
\end{abstract}

Keywords: Intervertebral disc degeneration, nucleus pulposus cells, annulus fibrosus cells, regeneration, hydrogels, synthetic polymers, natural hydrogels, delivery, cell-biomaterial interactions.

\footnotetext{
*Address for correspondence:

Laura Creemers

Dept Orthopaedics G05.228

Heidelberglaan 100
}

3584 CX Utrecht, The Netherlands

Telephone Number: +31 887550293

FAX Number: 31302510638

E-mail: 1.b.creemers@umcutrecht.nl

\section{Introduction}

The vertebral column is composed of the rigid bony vertebral bodies, interspersed with intervertebral discs (IVDs) and facet joints. It protects our spinal cord and supports our head, upper extremities and torso while providing flexibility in multiple degrees of freedom. The IVDs, in total making up about a third of the spinal column by height, enable movement of the spinal column and transfer the loads associated with movement. As non-vascular and non-synovial structures with limited repair capacities, the IVDs have been shown to be prone to cumulative damage. Chronic low back pain is strongly linked to lumbar IVD degeneration while radicular pain is associated with bulging of the posterior annulus fibrosus (AF) and nucleus pulposus (NP) herniation (Luoma et al., 2000). Back pain, as a result of IVD degeneration, can start early in life and will affect at least $60 \%$ of people over the age of 70 (Miller et al., 1988).

\section{The healthy IVD: Functional characteristics and relation to tissue structure}

The healthy IVD consists of a nucleus pulposus circumferentially surrounded by an AF and axially enclosed by two cartilaginous endplates (CEP) (Fig. 1). The NP mainly consists of proteoglycans and collagen type II, with a few cells interspersed in the matrix. Due to the presence of the highly charged proteoglycans with the concomitant attraction of cations, the tissue osmotic pressure is high. This in turn attracts water and due to the confinement by the AF and endplates generates hydrostatic pressure. When subjected to shear forces, the NP behaves as a viscoelastic material rather than a fluid (Iatridis et al., 1996). The AF is a fibrocartilaginous structure consisting of both collagen I and II and proteoglycans, where the collagenous layers are alternately arranged at angles of about $60^{\circ}$ and $150^{\circ}$ to the spinal longitudinal axis around the NP. Together with elastin-rich layers in between the collagen lamellae, the AF provides tensile strength and the capacity to withstand disc bulging in response to loading (Isaacs et al., 2014). The cartilaginous endplate that connects the IVD to the vertebral bodies consists of hyaline cartilage and transfers compressive forces due to axial loading to the NP. It is supported by the osseous part of the endplate of the vertebral bodies to which the AF collagen fibres are anchored. As the IVD matures, the large cytoplasmic vesicle-rich notochordal cells inside the NP are replaced by the smaller chondrocyte-like cells, 

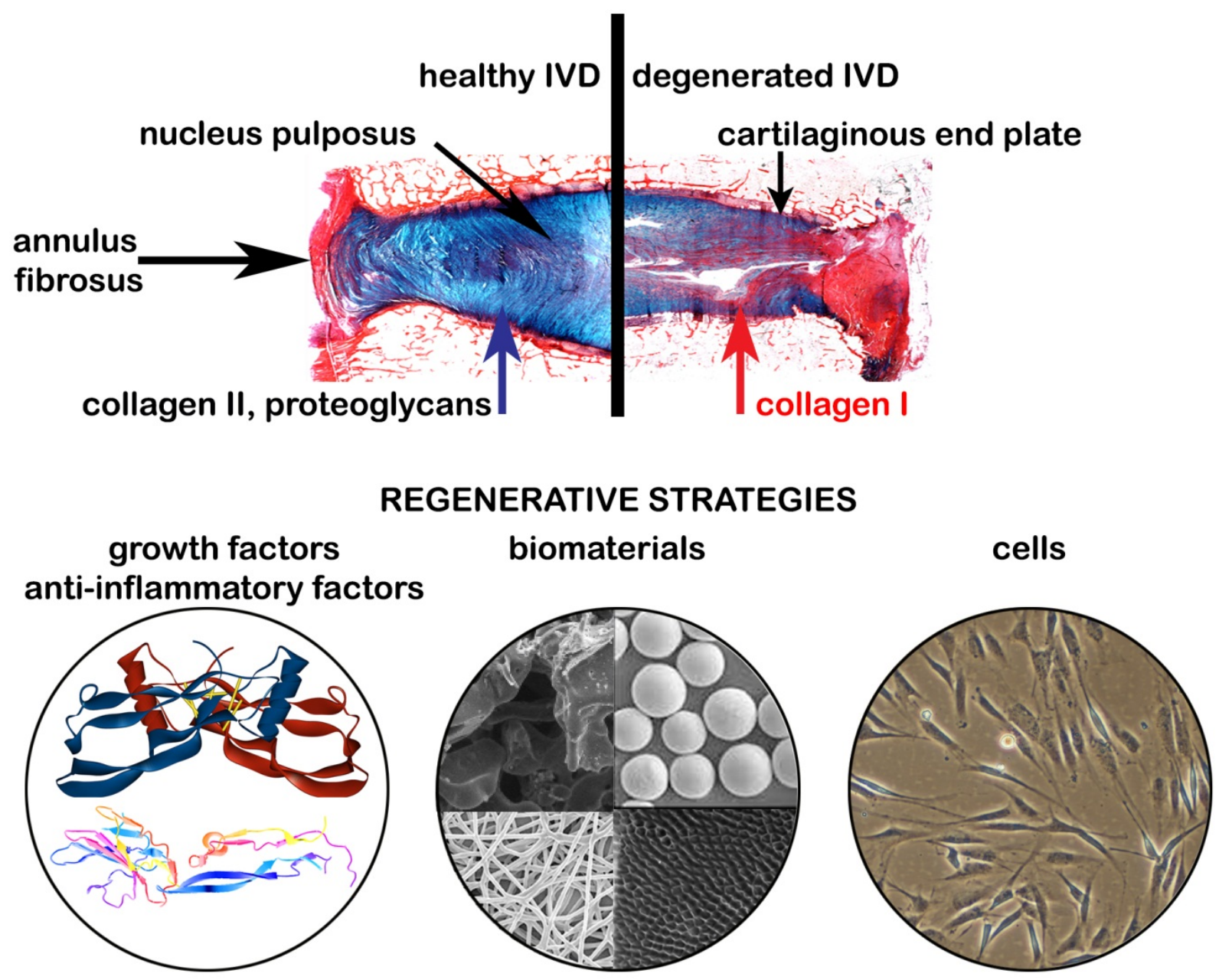

Fig. 1. Tools for regenerative treatments of the IVD. Upper left panel showing a healthy human disc, and on the right a degenerated disc. Below are depicted the main approaches towards regenerative medicine, i.e. the application of regenerative factors/factors inhibiting inflammation, biomaterials and exogenously added cells.

possibly by transdifferentiation (Hunter et al., 2004; Kim et al., 2009; McCann et al., 2012; Purmessur et al., 2013). In addition, NP progenitor cells have been identified with mesenchymal stem cell (MSC)-like marker expression and multipotency, also in the degenerate IVD (Risbud et al., 2007; Sakai et al., 2012). The AF contains fibroblast-like cells in its outer rim, whereas cells are more chondrocytic in appearance in the inner annulus.

\section{Pathophysiology and aetiology of IVD degeneration} Intervertebral disc degeneration is characterised by several biochemical and morphological changes. Proteoglycans and collagen type II in the NP are lost and replaced by fibrous tissue rich in collagen type I (Fig. 1). This eventually leads to a reduction in hydration and a loss in the ability to maintain osmotic pressure. The process of proteoglycan loss is due to enzymatic activity by which also collagen and fibronectin become increasingly fragmented (Martin et al., 2002; Urban and Roberts, 2003). Up to $50 \%$ of cells in severely degenerate discs appear necrotic (Trout et al., 1982).

The aetiology of IVD degeneration is still a subject of debate. The most commonly accepted theory is based on the concept that the IVD receives its nutrition from the cartilaginous endplate by diffusion towards the centre of the NP, although - controversially - diffusion or convection through the AF was also suggested (Cortes et al., 2014; Hutton et al., 2004; Urban et al., 1977; van der Veen et al., 2007). Occlusion of openings containing capillary endings in the bony endplate may reduce nutrient supply and oxygen saturation, affecting the $\mathrm{pH}$, matrix synthesis and eventually cell viability inside the IVD (Urban and Roberts, 2003). Subsequent loss of proteoglycans results in a lower hydration state, leading to a reduced weight bearing capacity. This allows inappropriate weight and stress distribution across the disc, resulting in stress fissures in the nucleus or the AF (Adams et al., 2014). Another mechanism of disc degeneration may be related to mechanical loading. IVD degeneration is associated with physically demanding professions (Luoma et al., 2000), suggesting intensive load bearing may induce degeneration, as supported by ex vivo experiments with overloading. Similarly, normal everyday loading may also cause lumbar IVD degeneration. This is supported by the observation that several polymorphisms associated with IVD degeneration involve genes encoding extracellular matrix proteins essential for the biomechanical properties of the IVD; amongst others, collagens (I, IX, XI), 


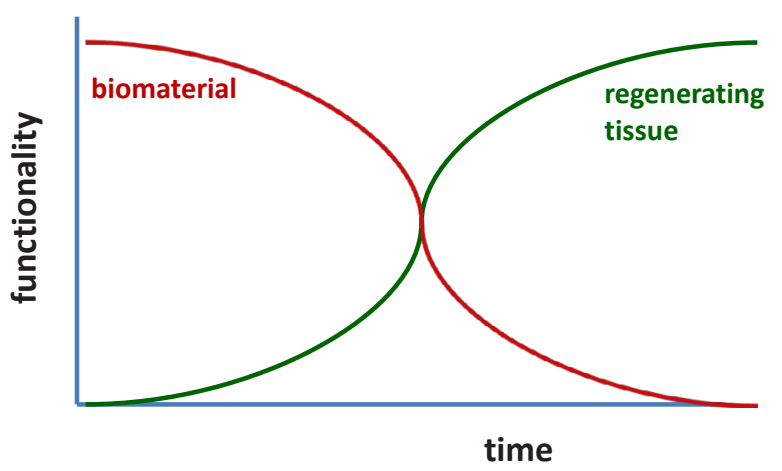

Fig. 2. Paradigm for optimal biomaterial-based regeneration of the IVD. Ideally, functionality of the IVD is maintained by biomaterial degradation occurring at the same speed as tissue regeneration.

aggrecan, hyaluronic acid synthase and also matrix degrading proteases including MMP-1, 2, 3 and 9 (Battie and Videman, 2006; Williams et al., 2012; Mayer et al., 2013; Näkki et al., 2014). These polymorphisms may also act through non-mechanical pathways. However, the current lack of meaningful odds ratios for correlation of disc degeneration and polymorphisms indicates that most likely multiple factors are involved in this condition.

\section{Regenerative medicine ( $R M)$ as emerging approach for IVD degeneration}

Current treatments of lower back pain mainly aim to treat its symptoms. Options for treatment include physiotherapy, analgesia, muscle relaxants, corticosteroids and surgery (discectomy, disc prosthesis or spinal arthrodesis) (Jacobs et al., 2013). Surgical treatment is highly invasive and although spinal fusion may reduce pain, it does not provide for biological repair and preservation of motion of the treated segment (Etebar and Cahill, 1999). Furthermore, spinal fusion has been associated with degeneration of adjacent IVDs (Higashino et al., 2010; Radcliff et al., 2013), although this partially may reflect the natural course of disc pathobiology (Helgeson et al., 2013). In terms of arthroplasty, no long-term effective and fully safe IVD substitute has been described until now (Thavaneswaran and Vandepeer, 2014). All in all, the current treatments are mere salvage treatments that are not very effective and/or even entail serious risks.

Therefore, research into novel treatment strategies focuses on regeneration of the IVD rather than addressing the effects of degeneration. For this purpose, three different components are being employed either alone or in combination: growth factors, cells and biomaterials (Fig. 1). Cells, in particular mesenchymal stromal cells (MSCs), and growth factors hold promise to directly regenerate IVD tissue by anabolic effects on the cell population and matrix homeostasis (Chan and Gantenbein-Ritter, 2012; Masuda, 2008; Richardson and Hoyland, 2008; Yim et al., 2014). In contrast, biomaterials can have several roles. They can be used as structural scaffolds (Darwis et al., 2002; Ella et al., 2005; Gloria et al., 2007; Joshi et al., 2006), improving disc height and mechanical stability of the vertebral segments, thereby correcting altered distribution of mechanical loads affecting cytoskeletal structure, gene transcription, and matrix biosynthesis (Chen et al., 2004; Iatridis et al., 1999; Setton and Chen, 2006). Biomaterials have also been used as cell carriers and release systems for active factors in order to achieve regeneration. Resident cells in the native IVD can migrate into hydrogels, providing a framework for regeneration by native cells (Anderson et al., 2005; Yang and $\mathrm{Li}, 2009$ ). The focus of this review is to explore the applicability of various biomaterials in IVD regeneration, with a focus on the NP and AF and on biodegradable biomaterials, as biostable materials (materials that do not degrade) are often implants and prostheses rather than elements contributing to regeneration of the IVD.

\section{Biomaterials for IVD regeneration}

To stimulate IVD regeneration, a biomaterial ideally possesses many different properties. It should provide some degree of immediate mechanical support and its degradation should occur in parallel with the formation of new and functional tissue, without the production of toxic by-products (Fig. 2). It should provide a permissive environment for seeded cells or for resident cells migrating into the biomaterial, allowing for diffusion of oxygen and nutrients required for tissue production. Cell differentiation and matrix production are achieved, induced either by active factors included or by intrinsic properties of the material or its constituent polymers.

Biomaterials are often divided into natural biomaterials and synthetic biopolymers, and come as hydrogels or solid scaffolds. Natural polymer-based biomaterials used include mainly hydrogels, such as chitosan, alginate, collagen, hyaluronan and agarose. The group of synthetic biomaterials comprises poly-(D,L-lactide) (PLA) and derivatives, polyethylene glycol (PEG), polycarbonate urethane (PU) and poly(epsilon-caprolactone) (PCL). Some of these synthetic biomaterials can serve either as solid scaffolds or as hydrogels. Overviews of the biomaterials used and their effects and properties are given in Tables 1, 2 and 3.

\section{Natural hydrogels \\ Chitosan}

Chitosan is a polysaccharide biopolymer composed of glucosamine and $\mathrm{N}$-acetyl glucosamine units and is derived from partial de-acetylation of chitin (Di Martino et al., 2005; Roughley et al., 2006). Medical applications include wound haemostasis and healing, based on antimicrobial properties as well as drug delivery capabilities (Dai et al., 2011; Patel et al., 2010; Pusateri et al., 2003). Both hydrogels and solid scaffolds can be formed from chitosan (Di Martino et al., 2005). Chitosan is dissolved at low $\mathrm{pH}$, so the final hydrogel needs to be neutralised before application. This presents a challenge as neutralisation of an acidic chitosan solution causes immediate cross-linking of chitosan chains.

Chitosan is degradable in vivo through lysozyme activity. Increasing the degree of de-acetylation prolongs its degradation time while enhancing cell adhesion (Mao et al., 2004; Di Martino et al., 2005). The cationic 


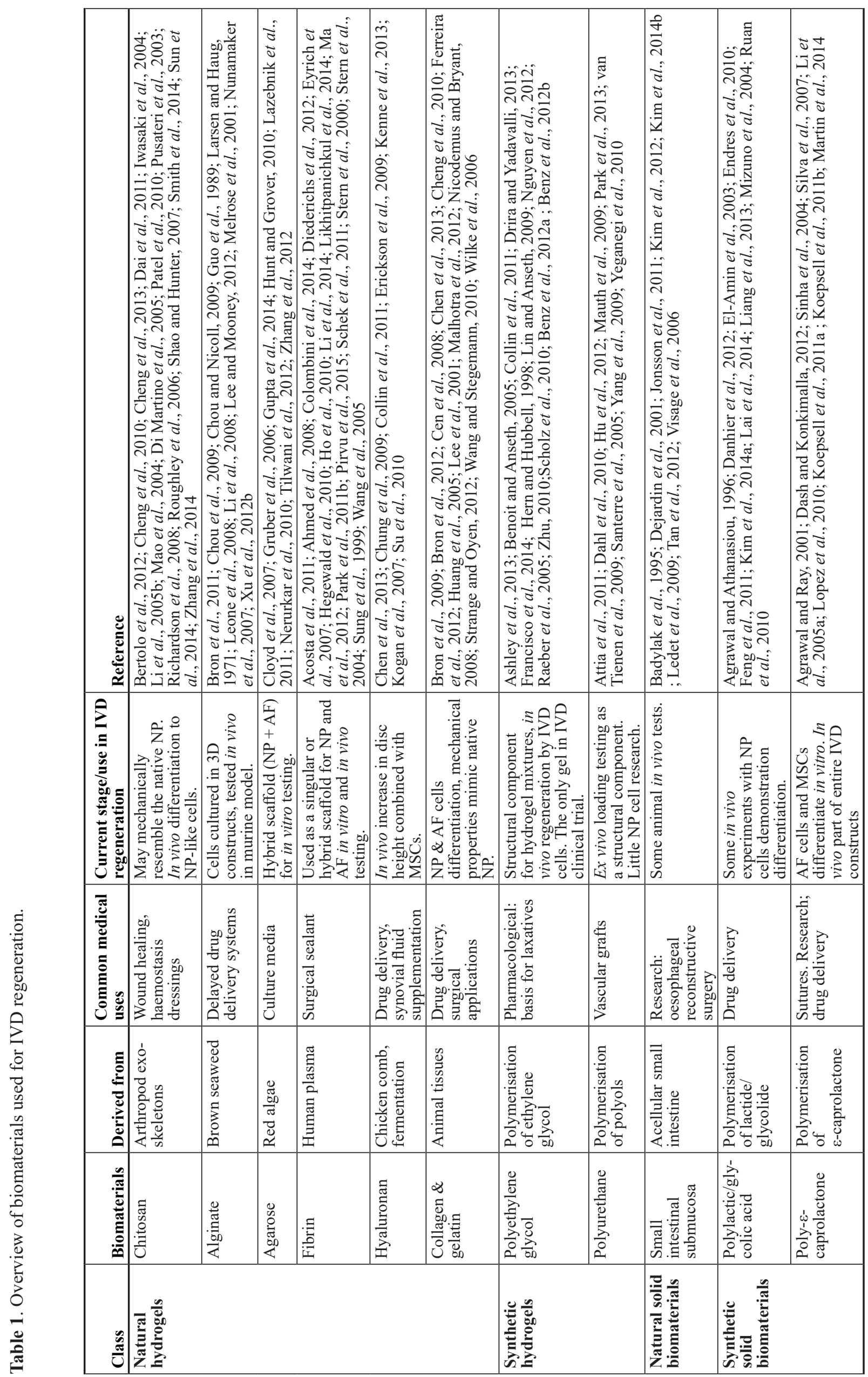


Table 2. Overview of characteristics of natural biomaterials used for IVD regeneration.

\begin{tabular}{|c|c|c|c|c|c|c|c|}
\hline Biomaterial & Chitosan & Alginate & Agarose & Fibrin & Hyaluronan & $\begin{array}{c}\text { Collagen / } \\
\text { gelatin }\end{array}$ & SIS \\
\hline Injectable as a liquid & + & + & + & + & + & + & - \\
\hline $\begin{array}{l}\text { Can harden in situ if } \\
\text { injected }\end{array}$ & - & + & + & + & + & + & - \\
\hline $\begin{array}{l}\text { Can provide } \\
\text { mechanical support }\end{array}$ & - & $+/-$ & $+/-$ & $+/-$ & $+/-$ & + & + \\
\hline Biodegradable & + & + & - & + & + & + & + \\
\hline Degradation: residue & - & - & + & - & - & - & - \\
\hline $\begin{array}{l}\text { Biocompatible: } \\
\text { including cell } \\
\text { seedability/migration }\end{array}$ & + & + & + & + & + & + & + \\
\hline $\begin{array}{l}\text { Stimulation } \\
\text { differentiation/ECM } \\
\text { production }\end{array}$ & + & + & + & + & + & + & + \\
\hline Swelling & - & + & + & $+/-$ & + & + & $+/-$ \\
\hline Extra properties & $\begin{array}{c}\text { Naturally } \\
\text { antimicrobial }\end{array}$ & $\begin{array}{l}\text { Degradation } \\
\text { not fully } \\
\text { understood }\end{array}$ & $\begin{array}{l}\text { Biodegradable } \\
\text { only as } \\
\text { mixtures }\end{array}$ & $\begin{array}{c}\text { Capability } \\
\text { to act as AF } \\
\text { defect sealant }\end{array}$ & & & \\
\hline
\end{tabular}

Table 3. Overview of characteristics of synthetic biomaterials used for IVD regeneration.

\begin{tabular}{|l|c|c|c|c|}
\hline Biomaterial & PEG & PLA / PGA & PU & PCL \\
\hline Injectable & + & - & - & - \\
\hline $\begin{array}{l}\text { Can harden } \text { in situ if } \\
\text { injected }\end{array}$ & + & - & - & - \\
\hline $\begin{array}{l}\text { Can provide mechanical } \\
\text { support }\end{array}$ & + & + & + & + \\
\hline Biodegradable & - & + & + & $+/-$ \\
\hline Degradation: residue & - & - & + & + \\
\hline $\begin{array}{l}\text { Biocompatible: including } \\
\text { cell seedability/migration }\end{array}$ & + & + & + & + \\
\hline $\begin{array}{l}\text { Stimulation differentiation/ } \\
\text { ECM production }\end{array}$ & + & + & + & - \\
\hline Swelling & + Biodegradable \\
Extra properties & & & + \\
\hline
\end{tabular}

nature of chitosan facilitates interaction with anionic glycosaminoglycans and binding of cytokines and growth factors (Di Martino et al., 2005).

However, chitosan gels tend to be much softer and more flexible than the native NP (Sasson et al., 2012). Biomechanical properties of chitosan scaffolds can be improved by the addition of other biomaterials, in particular alginate (Iwasaki et al., 2004; Li et al., 2005b) and gelatin (Cheng et al., 2010) without affecting cell viability and matrix production. A chitosan/dextran hydrogel implanted into human cadaveric spines and subjected to extensive loading did not show extrusion. Furthermore, Young's modulus and Poisson's ratio were found to be similar to human IVDs under unconfined compression. In vitro, NP cells cultured on top of the hydrogel remained viable and MSCs incorporated into the gel were able to chondrogenically differentiate as reflected by collagen type II and aggrecan production (Smith et al., 2014). Bovine NP cells cultured in chitosan scaffolds produced an extracellular matrix (ECM) similar to that of the native
$\mathrm{NP}$, and more so than bovine AF cells (Roughley et al., 2006). Canine AF cells cultured in alginate/chitosan scaffolds formed clusters and produced collagens I, II and aggrecan (Shao and Hunter, 2007). The addition of chitosan to alginate proved to increase degradation time for the scaffold.

Also, undifferentiated cells show a regenerative response to chitosan. Human MSCs differentiated to NPlike cells, produced collagen type II and aggrecan and remained viable up to $70 \%$ after 4 weeks in chitosanglycerol phosphate hydrogels (Richardson et al., 2008). However, compared to alginate or gelatin, chitosan was less chondrogenic for MSCs (Bertolo et al., 2012). Rabbit adipose tissue-derived MSCs differentiated towards NPlike cells on chitosan/alginate scaffolds under hypoxic conditions (Zhang et al., 2014). Rabbit bone marrowderived MSCs injected in chitosan-glycerophosphate hydrogels into lumbar NP defects in vivo, remained present up to 12 weeks and showed chondrogenic differentiation and ECM production, which was further enhanced by prior 
Sox9 transduction (Sun et al., 2014). Unfortunately, MSCs were never directly compared with NP cells in terms of regenerative capacity in chitosan gels.

Although chitosan is a versatile material, it must be used in combination with other materials to improve its biomechanical properties. The added value of using chitosan in this situation is induction of chondrogenic differentiation. The main drawback is that chitosan remains a difficult material to handle, because it forms a hydrogel only when dissolved in an acid.

\section{Highlights:}

- Degrades relatively slowly.

- Evidence in vivo is limited.

- Hydrogel preparation is complicated as neutralisation causes cross-linking.

- Chitosan is less suitable for MSC-based IVD regeneration than gelatin or alginate.

\section{Alginate}

Alginate (alginic acid) is a natural biopolymer derived from brown seaweed, generally composed of beta(1-4)linked D-mannuronic acid (M) and alpha(1-4) linked L-guluronic acid (G) moieties (Bron et al., 2011; Larsen and Haug, 1971). Alginate-based gels can be cross-linked through ionic, covalent and thermal processes. The latter two require modification of alginate and addition of thermosensitive hydrogels (Lee and Mooney, 2012; Nunamaker et al., 2007). Medical applications of alginate include local drug release and wound dressings (Lee and Mooney, 2012). In vivo degradation is dependent on the process of removing links between chains (Lee and Mooney, 2012). In vivo, alginate induces negligible immunological reactions (Leone et al., 2008; Li et al., 2008; Nunamaker et al., 2007).

Alginate hydrogel stiffness can be regulated by changing its alginate weight/volume $(\mathrm{w} / \mathrm{v})$ percentage (Bron et al., 2011). $2 \%$ (w/v) alginate scaffolds resemble the native NP in terms of stiffness (Bron et al., 2011). Furthermore, $2 \%$ alginate hydrogels cross-linked with $0.025 \mathrm{M} \mathrm{CaCl}_{2}$ achieved aggregate moduli (1.2 MPa) similar to the native IVD (Foss et al., 2014). Alginate-based materials are often combined with synthetic polymers such as poly (epsilon-caprolactone) (PCL) or polyglycolide (PGA) to further enhance mechanical properties (Xu et al., 2012). Alginate itself is often added to natural hydrogels for its easy to control cross-linking properties (Iwasaki et al., 2004; Shao and Hunter, 2007; Zhang et al., 2014).

Photocrosslinking alginate not only improved mechanical characteristics but also allowed for enhanced ECM synthesis in vivo by pre-loaded bovine NP cells, when compared to non-photocrosslinked gels (Chou et al., 2009; Chou and Nicoll, 2009). In addition, AF, NP and CEP-derived stem cells were shown to proliferate and produce ECM in alginate hydrogels, albeit with distinct differences between the cell types (Melrose et al., 2001; Wang et al., 2014). In vivo, combination with CEP-derived cells resulted in better NP regeneration in a rabbit model of induced disc degeneration compared to AF- and NPderived cells (Wang et al., 2014). Further enhancement of NP cell differentiation and matrix production was achieved by adding glucosamine and chondroitin sulphate to alginate
(Foss et al., 2014). The addition of collagen to alginate scaffolds not only promoted proliferation of seeded AF cells and MSCs in vitro, but also induced the migration of endogenous AF cells in vitro, although in all cases only collagen I and not collagen II was produced (Guillaume et al., 2014). Other cues enhancing regeneration and differentiation inside alginate gels are RGD peptides, which have been shown to facilitate chondrogenic differentiation of human MSCs (Re'em et al., 2010).

Altogether, alginate is a very versatile material that shows definite promise as a scaffold for regeneration of especially the NP. The main drawback of using this material is that the mechanism of degradation in vivo is not fully understood yet.

\section{Highlights:}

- Alginate is easy to use and its physical and chemical characteristics are well described.

- It is versatile and is very well suited as a structural addition to almost any hydrogel blend.

- Alginate is mostly used for NP regeneration.

- The degradation pathway of alginate in vivo is unclear, further research should focus on determining if this interferes with regeneration for the NP.

\section{Hyaluronan}

Hyaluronan or hyaluronic acid (HA) is a connective tissue polysaccharide consisting of repetitive units of D-glucuronic acid and N-acetyl-D-glucosamine residues (Kenne et al., 2013), extensively studied for the purpose of tissue regeneration (Collins and Birkinshaw, 2013; Kim et al., 2011). Hyaluronan derivatives are clinically applied for drug delivery and surgical procedures (Kogan et al., 2007).

Biodegradation of HA occurs by the action of hyaluronidases and degradation rate can be adjusted by the incorporation of methacrylate groups also used for photocrosslinking (Kim et al., 2011). Adjusting the w/v percentage of HA hydrogels or using HA with a greater molecular weight increases the stiffness, up to close to that of native NP, although it reduces the ability to withstand shear forces, which negatively influences hydrogel integrity (Chen et al., 2013). In composite hydrogels, ECM production can be influenced by using dynamic hydrogels, i.e. hydrogels changing in physicochemical properties, for example at a particular high $\mathrm{w} / \mathrm{v}$ percentage and hence stiffness, which reduces over time by hydrolytic action on caprolactone units (Chung et al., 2009).

For IVD regeneration with HA, mainly NP cells and MSCs have been studied (Chung et al., 2009; Cloyd et al., 2007; Collin et al., 2011; Su et al., 2010). NP cells retain their rounded morphology while demonstrating a high viability in oxidised-HA gels (Chen et al., 2013). Furthermore, it was demonstrated that the presence of HA facilitates their matrix synthesis as determined by GAG content (Peroglio et al., 2012). HA hydrogels are often mixed with other natural hydrogels such as gelatin or with synthetic polymers, usually polyethylene glycol (PEG) (Collin et al., 2011; Frith et al., 2013). The addition of gelatin provides viscoelastic properties (shear modulus) resembling the native NP, while NP cells cultured on this combination still show regeneration (Chen et al., 2013). In particular, gels containing lower molecular weight HA 
combined with PEG were found to facilitate NP and AF cell proliferation (Jeong et al., 2014).

MSCs can bind to HA through the cell surface receptor CD44 (Kota et al., 2014). However, although higher density HA hydrogels enhance ECM production and retention by bone marrow derived MSCs, even distribution of ECM throughout the construct is limited (Erickson et al., 2009). Several animal in vivo studies have been performed, each demonstrating that the injection of MSCs with HA into degenerate discs stimulates some regeneration as measured by restoration of disc height (Crevensten et al., 2004; Ganey et al., 2009; Ghosh et al., 2012).

$\mathrm{HA}$ is an interesting material for IVD regeneration because it is an integral part of the native IVD. Its main setbacks are the differential effects of molecular weight and the choice of biomaterial to be combined with. Higher molecular weight HA resembles the IVD mechanically but inhibits cell function, which benefits from lower molecular weight formulations.

\section{Highlights:}

- Hyaluronic acid is a very versatile biomaterial, is biocompatible and relatively easy to handle.

- Its chemical structure allows for adhesion of many different cell types examined for IVD regeneration.

- HA as scaffold shows great potential for NP regeneration.

- Depending on its molecular weight, HA may also be a good additive to synthetic hydrogels to stimulate ECM formation.

\section{Collagen and gelatin}

Collagen is one of the most abundant proteins found in the human body, making up about one third of our total protein weight (Ferreira et al., 2012). Gelatin is a material derived from animal collagen usually through thermal denaturation. Both are biodegradable and their degradation results in non-toxic by-products (Huang et al., 2005; Lee et al., 2001; Nicodemus and Bryant, 2008). Current medical uses include applications in plastic and reconstructive surgery and as a vehicle for drug delivery (Ferreira et al., 2012). Collagen type I as a hydrogel is also investigated for bone and soft tissue regeneration (Badylak et al., 2009; Bron et al., 2012; Cen et al., 2008; Ferreira et al., 2012).

Collagen I hydrogels can attain rheological properties resembling the native NP when compressed (Bron et al., 2009). When implanted inside damaged ex vivo bovine IVDs, the collagen matrix was able to restore disc height and mechanical behaviour of the spinal segment. The main issue reported is implant extrusion (Wilke et al., 2006). Hydrogel stiffness can be adjusted by changing the w/v percentage (Bron et al., 2009). Native caprine NP and AF cells successfully migrated into $3.0 \%$ collagen type I scaffolds, which was dependent on collagen digestion by the migrating cells (Bron et al., 2012). Human adiposederived stromal cells seeded on elastin-glycosaminoglycancollagen I composite hydrogels attained an NP-like morphology (Mercuri et al., 2014). Gelatin, mostly derived from collagen I, is often used in composite hydrogels to improve biomechanical properties. Addition of gelatin to HA improves viscoelastic properties (Chen et al., 2013; Malhotra et al., 2012). Similarly, addition of gelatin to chitosan hydrogels improved rheological properties and left cell viability unaffected (Cheng et al., 2010). Addition to agar hydrogels increased equilibrium elastic behaviour to that of the native NP, due to enhanced osmotic swelling (Strange and Oyen, 2012). The addition of gelatin to other hydrogels not only influences the mechanical properties but also has the ability to improve the microenvironment for NP cells, because gelatin, like collagen, contains regions that allow for cell attachment e.g. RGD motifs (Chen et al., 2013).

In vivo, gelatin-based hydrogels could suppress the progression of IVD degeneration in a rabbit model of NP aspiration (Nagae et al., 2007). Also, the injection of cell-free gelatin-based microspheres into a rabbit disc degeneration model showed less apoptosis in the NP than IVDs without this treatment (Sawamura et al., 2009).

In conclusion, collagen and gelatin hydrogels, much like HA, are interesting because they form an integral part of the ECM, thereby improving cell adhesion. Collagen hydrogels can prove difficult to work with, because they easily denature at temperatures above $37{ }^{\circ} \mathrm{C}$ (Ferreira et al., 2012). They can be blended into other hydrogels in different forms, so as to enhance the drug/growth factor release profiles as well as enhance the compatibility of a composite hydrogel.

\section{Highlights:}

- Gelatin/collagen is one of the best-understood natural biomaterials.

- Mechanical properties are well understood.

- Currently widely examined for other RM purposes and controlled release strategies.

- A good addition to any hydrogel blend for its structural and cell binding properties.

- Promising for NP regeneration.

- Further research should focus on studying this material in vivo.

\section{Agarose}

Agarose is a polysaccharide derived from algae and composed of monomer agarobiose units consisting of one D-galactose and one 3,6-anhydro-L-galactopyranose. Agarose gels when mixed with water provide a 3-dimensional helical structure (Gruber et al., 2006). Agarose by itself is non-degradable in vivo. Composites containing agarose degrade by degradation of the added hydrogel components, resulting in fragmentation of agarose over time. Therefore, complete degradation is not guaranteed (Hunt and Grover, 2010). Degradation time is controllable by changing composite component concentrations. None to mild immunological responses were noted in vivo in subchondral cartilage defects (Gupta et al., 2014). Human AF cells cultured in agarose produced more GAGs than in collagen sponges but proliferated less. To what extent collagen sponges can be considered truly $3 \mathrm{D}$ is unclear; however, as in sponges with large pores, cells may not be surrounded by the biomaterial but rather are attached to the pore surfaces (Gruber et al., 2006). Agarose, in combination with a synthetic electrospun polymer, mimicked the IVD in compression and torsion tests, with agarose as NP and the electrospun polymer as AF (Nerurkar et al., 2010). MSCs seeded on these composite structures produced ECM components (Lazebnik et al., 
2011; Nerurkar et al., 2010). Bovine NP cells cultured in agarose hydrogels infused with transforming growth factor-beta (TGF- $\beta$ ) were capable of responding to cyclical compressive loading with increased matrix synthesis and gene expression (Tilwani et al., 2012).

Research groups are combining agarose into natural/ synthetic composite scaffolds to allow more comprehensive mechanical testing of NP-AF analogues. Agarose hydrogels singularly may not suffice for regeneration of the IVD, but it holds promise as a structural component to other hydrogel formulations.

Highlights:

- Particularly interesting for NP regeneration as structural component for hydrogel blends.

- It is a relatively difficult material to work with, as it remains liquid only at high temperatures.

- As a single hydrogel, it has limited use, especially since it is non-degradable in vivo.

\section{Fibrin}

Fibrin is a protein associated with the blood coagulation pathway. It is used in medicine as a sealant. Fibrin is biocompatible and non-immunogenic (Ahmed et al., 2008). Physical scaffold characteristics can be adjusted by adjusting the concentration of $\mathrm{Ca}^{2+}$, fibrinogen and thrombin. Fibrinogen concentrations above $25 \mathrm{mg} /$ $\mathrm{mL}$ combined with $\mathrm{Ca}^{2+} 20 \mathrm{mmol} / \mathrm{L}$ produced hydrogel constructs that remained stable for up to 3 weeks (Eyrich et al., 2007). Fibrin is often combined with other materials such as silk, HA or PGA (Colombini et al., 2014; Hegewald et al., 2010; Park et al., 2011b; Stern et al., 2004). The addition of silk-fibroin to fibrin/HA hydrogels provides greater mechanical strength than fibrin/HA hydrogels alone while preventing shrinkage in vivo (Park et al., 2011b). In fibrin/HA hydrogels, porcine NP cells showed more proliferation and proteoglycan production compared to alginate culture (Stern et al., 2000). Fibrin/HA cultured with bovine NP cells and injected in a nucleotomy defect in organ culture, demonstrated better integration with native NP tissue compared to fibrin hydrogels without the addition of HA, while restoring disc height, with a compressive stiffness similar to native NP levels (Li et al., 2014).

Fibrin/genipin based hydrogels have been tested as adhesives for AF repair. Genipin is an aglycone derived from the Gardenia fruit with excellent crosslinking properties at low toxicity (Sung et al., 1999). A combination of fibrin/genipin hydrogels improved in vivo hydrogel longevity compared to fibrin-only hydrogel scaffolds in a subcutaneous model in rats (Likhitpanichkul et al., 2014). In a bovine ex vivo AF defect model, fibrin/genipin hydrogels prevented disc height loss and remained integrated after more than 10,000 cycles of loading (Likhitpanichkul et al., 2014). Furthermore, it was demonstrated that AF cells remained viable and migrated into fibrin/genipin hydrogels (Likhitpanichkul et al., 2014; Schek et al., 2011). Fibrin hydrogels functionalised with TGF- $\beta$ stimulated human MSCs (hMSC) to undergo chondrogenesis, although soluble TGF- $\beta$ resulted in a more profound induction of regeneration (Diederichs et al., 2012). A fibrin/alginate blend of $40: 8 \mathrm{w} / \mathrm{w}$ was able to promote MSC proliferation as well as GAG and collagen type II production while combining physical characteristics of alginate and fibrin hydrogels (Ma et al., 2012). The main problem reported was formation of islands of alginate in the fibrin hydrogel. Moreover, at a w/w $\%$ content of 0.6 or above, alginate interfered with chondrogenesis (Ho et al., 2010). Fibrin injected in solid poly(trimethylene carbonate) scaffolds as repair strategy in an ex vivo annulus defect model, resulted in GAG deposition after 14 days of culture. However, this appeared independent of the incorporated MSCs (Pirvu et al., 2015).

In vivo fibrin was tested as a cell carrier for IVD regeneration in a mini-pig needle nucleotomy model. Chondrocytes proved to be more effective in restoring disc height and matrix production than MSCs or cell free controls (Acosta et al., 2011).

Fibrin is a promising biomaterial for use as a cellular scaffold. It has excellent biocompatibility, combined with the ability to stimulate chondrogenesis. Fibrin can be considered for any blend of hydrogels for intervertebral disc regeneration. The main associated drawback is that fibrin is readily degraded by enzymatic action in vivo; cross-linking, however, can overcome this challenge. Despite the widespread use of fibrin in medical practice, there are as yet no on-going clinical trials using fibrin as a basis for IVD regeneration.

\section{Highlights:}

- Fibrin shows excellent promise as a cellular scaffold whereby extensive ECM production can be achieved by a wide variety of cell types.

- It has excellent biocompatibility.

- Fast degradation in vivo; requires modification for in vivo use for extended periods of time.

- Fibrin can be used for both AF and NP regeneration.

- Further research into understanding the biomechanical properties should be performed.

\section{Synthetic hydrogels}

Synthetic hydrogels are mainly based on polymer networks that can absorb large amounts of water. They are characterised by their ease of modification. In addition, self-assembling peptide hydrogels have been a recent focus of attention (Loo et al., 2012); however, as only two publications have described their application for NP incorporation (Tao et al., 2014; Wang et al., 2012), these are not further discussed.

\section{Polyethylene glycol}

Polyethylene glycol (PEG) is a synthetic polyether that is manufactured through the polymerisation of ethylene glycol and carries the molecular formula $\mathrm{C}_{2 \mathrm{n}} \mathrm{H}_{4 \mathrm{n}+2} \mathrm{O}_{\mathrm{n}+1}$. In medical practice, it forms the basis for laxatives, due to its induction of water absorption, which also makes it an interesting biomaterial for NP regeneration. Like many other hydrogels, PEG is the subject of research in the field of controlled drug delivery (Ashley et al., 2013; Lin and Anseth, 2009). Although PEG-based hydrogels exhibit a similar range of biomechanical properties (compression modulus, tensile strength and hydrostatic swelling) as articular cartilage (Nguyen et al., 2012), it is rarely used for RM research as a stand-alone hydrogel as they are non-cell adhesive (Zhu, 2010). Therefore PEG hydrogels 
for RM goals should be functionalised with cell adhesive peptides such as RGD sequences (Benoit and Anseth, 2005; Hern and Hubbell, 1998) or mixed with hydrogels that do allow for adhesion (Collin et al., 2011; Drira and Yadavalli, 2013; Zhu, 2010).

Biodegradation of PEG-based gels can be achieved through the addition of synthetic or natural components such as polylactide or enzyme-sensitive peptides (Raeber et al., 2005; Zhu, 2010). This approach is particularly useful for photopolymerised hydrogels, where crosslinking typically reduces biodegradation. Porcine NP cells encapsulated in laminin-functionalised PEG hydrogels (Francisco et al., 2014) produced collagen and GAGs, which was enhanced in the softer PEG-laminin hydrogels compared to PEG-only hydrogels. Recently, a new PEGbased gel covalently linked to serum albumin and mixed with high molecular weight HA has come close to clinical application. The gel, which has anti-angiogenic properties in vitro and in vivo, showed an increased expression of collagen II and aggrecan in cells isolated from human IVD tissue harvested in the course of spinal fusion surgery (Benz et al., 2012a; Scholz et al., 2010). In this hydrogel, cartilaginous matrix production was not only found in vitro, but also after subcutaneous implantation in immune deficient mice, with most matrix formation around cells of human origin (Benz et al., 2012a). However, application of a gel-IVD cell construct in a sheep model of nucleotomyinduced IVD degeneration could not provide information on the capacity of the gel to mitigate disc degeneration, as all IVDs healed spontaneously, but no adverse effects of gel administration were found either (Benz et al., 2012b). Despite a lack of clear evidence for disc regeneration in vivo, a randomised clinical trial was initiated for patients with disc herniation (Web ref. 1).

PEG hydrogels are promising candidates for IVD regeneration because of their proven ease in use and adjustability. Furthermore, PEG hydrogels could be considered as additions to any hydrogel formulation.

\section{Highlights:}

- Easy to synthesise and adjust for RM purposes, especially for NP regeneration.

- Biomechanical properties are conducive for IVD regeneration.

- There are no attachment motifs for cells; therefore, functionalisation or blending is required.

- Can be useful as an addition to any hydrogel blend.

- Further research should focus on modifying PEG hydrogels for cell attachment.

\section{Polyurethane}

Polyurethanes or polycarbonate urethanes (PU) are materials normally used to produce hard plastics for applications such as electrical circuit housings. They have, however, been widely used in the medical world for years where they form the basis for vascular grafts (Santerre et al., 2005; Tiwari et al., 2002). Current research focuses on PU scaffolds for cartilage repair (Hung et al., 2014; van Tienen et al., 2009). PU and its derivatives are generally biodegradable, in vivo degrading to water and carbon dioxide (Santerre et al., 2005; Yang et al., 2009). These by-products do not affect the local $\mathrm{pH}$ as much as poly(lactide-co-glycolide), reducing negative effects on the microenvironment (Yang et al., 2009). Biomechanical functionality appears to be promising, as PU hydrogels injected in human cadaveric spines could withstand loading compression (Dahl et al., 2010). The PU hydrogel translated compression forces to the $\mathrm{AF}$ in a similar fashion as the native NP.

Various PU composite scaffolds have been created, with PU/silk fibroin (SF) hydrogels as the main example (Hu et al., 2012; Park et al., 2013). The addition of silk to PU scaffolds provides control over the degradation rate and mechanical properties. PU/SF scaffolds were used to replace the NP in cadaveric porcine spines by injection into the NP cavity (Hu et al., 2012). To scaffolds made of electrospun PU, AF cells attached and produced ECM components (Yeganegi et al., 2010; Attia et al., 2011). The addition of fibrin or fibronectin as cell attachment proteins further improved cell attachment to PU scaffolds (Mauth et al., 2009, Yeganegi et al., 2010). Furthermore, rabbit BMSCs proved to remain viable when seeded in a $\mathrm{PU} / \mathrm{SF}$ hydrogel and produced extensive ECM.

PU-based scaffolds hold promise for IVD regenerative strategies mainly due to their ease of use and the excellent track record with biocompatibility in medicine and medical research. The disadvantage of PU as a scaffold is mainly that very little research into NP cell and PU scaffold interaction has been conducted.

\section{Highlights:}

- PU scaffolds are highly biocompatible and easy to manufacture in different forms (gels and electrospun scaffolds).

- The PU/SF composite has shown promise as a scaffold for NP and electrospun PU for AF regeneration.

- Only few data are available on the response of NP cells to PU.

\section{Natural-based solid biomaterials}

Solid biodegradable scaffolds are usually preformed before implantation. They can have many of the same characteristics of hydrogels and function in a similar way. They are, however, not injectable through a needle, but may still be used in minimally invasive surgery. The advantage of using solid scaffolds over hydrogels is that mechanical properties are generally easier to control and better mechanical support can be provided. Among the natural-based solid scaffolds, small intestinal submucosa has been investigated most intensively. In addition, in vitro regenerative capacities for AF and NP cells were shown of silk-based scaffolds (Chang et al., 2010; Zeng et al., 2014; Park et al., 2012), which due to the limited number of studies are not further described.

\section{Small intestinal submucosa}

Small intestinal submucosa (SIS) is derived from the usually porcine - intestine. It is currently investigated for oesophageal reconstructive surgery and regenerative restoration of soft tissue and tendon defects (Badylak et al., 1995; Dejardin et al., 2001; Jonsson et al., 2011; Tan et al., 2012).

SIS contains growth factors such as TGF- $\beta$ (Le Visage et al., 2006). In vitro, SIS scaffolds provided suitable 
environments for AF and NP cells to produce ECM (Le Visage et al., 2006). Although an organised regenerated structure failed to be produced upon application of a SIS scaffold after box annulotomy in sheep, the scaffold did increase the hydration state of the annulus fibrosus and improved mechanical functionality (Ledet et al., 2009). Biomechanical properties could be further improved by combination with poly(lactide-co-glycolide) (PLGA); this combination also resulted in greater NP cell adhesion and ECM production in the composite scaffold (Kim et al., 2014b).

SIS is a material that needs further research to determine whether it can be used successfully in vivo for the regeneration of the IVD. However, the main concern with using decellularised animal matrices is the potential transfer of disease and immunogenicity.

\section{Highlights:}

- An ill-defined material that may show promise as a cellular scaffold, in particular for annulus repair.

\section{Synthetic solid biomaterials}

There are several synthetic materials that can be used in preformed solid scaffold configuration. Although there only are a few options, they are important to discuss because they hold great promise.

\section{Poly(lactide/glycolide)}

Polylactide (PLA) and polyglycolide (PGA) are synthetic polymers with the respective chemical formulae $\left(\mathrm{C}_{3} \mathrm{H}_{4} \mathrm{O}_{2}\right)_{n}$ and $\left(\mathrm{C}_{2} \mathrm{H}_{2} \mathrm{O}_{2}\right)_{\mathrm{n}}$. Several different formulations of PLA have been used: poly(L-lactide) (PLLA)and poly(D,L-lactide) (PDLLA) which is a racemic mixture, while PGA is not racemically structured. However, a composite of PLA and PGA termed poly(lactide-co-glycolide) (PLGA) appears most interesting for RM. Osteoblasts adhered better to PLGA scaffolds than single PLA or PGA scaffolds, probably due to better cell adhesion properties of the composite scaffolds (El-Amin et al., 2003). Degradation of PLGA, through hydrolysis of ester linkages, results in the production of lactic and glycolic acids which are naturally present in the human body and hence non-toxic (Danhier et al., 2012), although ensuing local acidification may be harmful (Agrawal and Athanasiou, 1996; Ding and Schwendeman, 2008). PLGA has Food and Drug Administration (FDA) approval for use in the human body for controlled drug release applications, where it is also the subject of much research (Lai et al., 2014). However, very little biomechanical data are available on PLGA scaffolds used for IVD regeneration.

Also, NP cells seeded on PLGA scaffolds and subcutaneously implanted in mice produced extensive ECM in scaffolds with small pores (90-250 $\mu \mathrm{m})(\mathrm{Kim}$ et al., 2014a). In vitro, adipose-derived stem cells have been shown to initiate chondrogenesis when seeded on PLGA scaffolds as measured through collagen type II expression. Upon implantation into pouches in nude mice, chondrogenesis was reflected by mRNA for collagen type II, aggrecan and other chondrogenic genes (Mehlhorn et al., 2009). PLGA constructs seeded with NP cells and inserted into the IVD of beagle dogs maintained disc height better than no implant or PLGA constructs alone (Ruan et al., 2010), although in a rabbit model of disc degeneration, cellfree scaffolds showed migration of cells and chondrogenic matrix production after 12 months (Endres et al., 2010). PLGA microsphere scaffolds seeded with adipose-derived stem cells were able to partially regenerate the IVD in rats after 24 weeks, where the addition of cells over cell-free scaffolds demonstrated a clear added value (Liang et al., 2013).

PLGA scaffolds are interesting because they have excellent biocompatibility and are widely studied as drug release systems, which has added value for any IVD regenerative implant.

\section{Highlights:}

- PLA, PGA and PLGA have good biocompatibility.

- PLGA shows promise for NP regeneration, but AF regeneration was not studied.

- PLGA could be used for combining drug delivery with regeneration.

- Further research should focus on biomechanical properties relevant for IVD regeneration.

\section{Poly(-غ-caprolactone)}

Poly(epsilon-caprolactone) (PCL) is a synthetic polyester produced through the polymerisation of $\varepsilon$-caprolactone $\left(\mathrm{C}_{6} \mathrm{H}_{10} \mathrm{O}_{2}\right)$. PCL is biodegraded through hydrolysis of the ester linkages, but degradation takes months to years, far slower when compared to other materials such as PLGA. The degradation time can be reduced by the addition of poly(vinylalcohol) (PVA) or PGA into the polymer chain (Dash and Konkimalla, 2012; Sinha et al., 2004). PCL is approved for use in the human body by the FDA and as such has been part of various medical applications for years, such as medical sutures. PCL has currently undergone a resurgence in research for the purpose of controlled drug release (Agrawal and Ray, 2001; Dash and Konkimalla, 2012; Silva et al., 2007).

PCL is interesting for regeneration of the AF because electrospun PCL fibres can mimic an AF fibre structural alignment (Koepsell et al., 2011b). It was shown that organised alignment by electrospinning induces ECM production by porcine AF cells on PCL scaffolds (Koepsell et al., 2011a). PCL was previously demonstrated to be a good carrier of human bone marrow derived MSCs (Li et al., 2005a), when cultured in 3D for 21 days extensively produced chondrogenic ECM. PCL as part of a whole IVD replacement scaffold was shown to hold promise for regeneration of the IVD (Martin et al., 2014).

PCL-based scaffolds usually have to be pre-shaped before implantation, but the addition of other synthetic scaffold materials allows the production of injectable hydrogels together with PCL. The addition of PCL into a synthetic hydrogel also allows the hydrogel to function as scaffold for the longer term (Lopez et al., 2010).

\section{Highlights:}

- PCL is an FDA-approved material for use in the human body.

- Holds promise as an AF regeneration component due to its high tensile strength.

- Little use for this material as a NP structural component. 
- Can be used as hydrogel in combination only or as a material to reinforce hydrogel structures.

- In vivo tests with PCL as part of a composite disc-like structure for whole IVD replacement/regeneration.

\section{Biomaterials as sustained delivery agents in IVD regeneration}

In addition to their role in supporting native or exogenously added cells, scaffolds, either solid or hydrogel-based, can be used for the delivery of cues required for regeneration. Several bioactive substances have been incorporated into delivery systems for IVD regeneration, including regenerative factors, such as growth factors and hormones, but also anti-oxidant and anti-inflammatory factors targeting mechanisms of cell senescence and matrix catabolism. Thus far, mostly nano- and microstructured injectable biomaterials have been used to achieve sustained release and are also discussed here, although they do not have a biomechanical nor intrinsic regenerative role in this type of application. For a general overview of materials for potential use as delivery vehicles, readers are referred to (Blanquer et al., 2012).

\section{Natural hydrogels}

In the degenerated IVD, apoptosis and senescence related to reactive oxygen species (ROS) production rises with increasing degeneration (Heathfield et al., 2008). Ferulic acid, a strong anti-oxidant, loaded onto an injectable thermosensitive chitosan/gelatin/glycerol phosphate hydrogel was shown in vitro to decrease hydrogen peroxide-induced oxidative stress of NP cells and reduce the levels of cell apoptosis. Moreover, sustained release of ferulic acid resulted in matrix anabolism, at the gene and protein level (Cheng et al., 2011; Cheng et al., 2013).

Biodegradable gelatin hydrogel microspheres impregnated with several poly-ionic growth factors released bioactive factors in a sustained fashion (Tabata $e t$ al., 1999) and upon impregnation with platelet-rich plasma (PRP), have been shown to inhibit IVD degeneration in vivo in a rabbit model of induced IVD degeneration (Nagae et al., 2007). Partial prevention of IVD height loss, increased gene expression levels of proteoglycan core protein and type II collagen, and a lower number of apoptotic cells compared to microsphere-only controls was noted. As this study was performed in a rabbit model with very mild IVD degeneration, additional studies are required to show proof of concept in moderate to severe IVD degeneration.

The release of chemokines to attract endogenous stem cells was shown as a promising alternative approach towards regeneration, as demonstrated by the enhanced attraction of MSCs by injection of stromal cell-derived factor-1 (SDF-1)-loaded HA hydrogels in an ex vivo nucleotomy model, with a clear added value over SDF-1 injected directly (Pereira et al., 2014).

\section{Synthetic hydrogels}

Intra-discal injection of a poly-N-isopropylacrylamide (pNIPAAM)-LDH-based hydrogel releasing celecoxib to

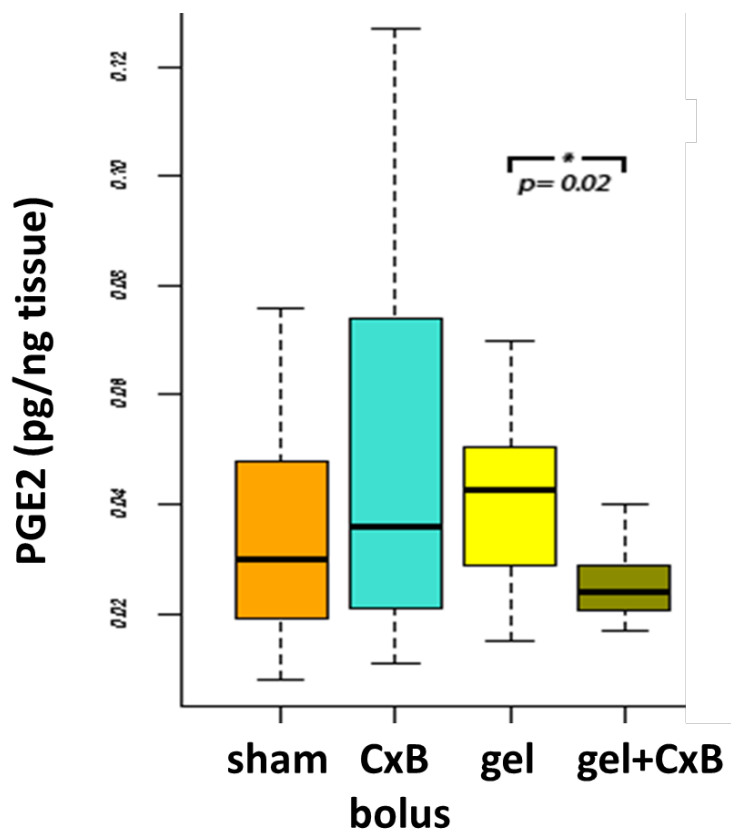

Fig. 3. Inhibition of $\mathrm{PGE}_{2}$ production by hydrogelmediated controlled release of celecoxib in a canine model of spontaneous disc degeneration. A PNIPAAMbased thermoreversible hydrogel was loaded with celecoxib (gel $+\mathrm{CxB})$ and injected in a canine model of spontaneous disc degeneration. Controls were unloaded gel (gel), sham injection (sham), and $\mathrm{CxB}$ alone ( $\mathrm{CxB}$ bolus).

specifically inhibit cyclooxygenase-2 (COX-2) activity showed a constant, albeit minor reduction of inflammation in a canine model of spontaneous IVD degeneration (Fig. 3; Willems et al., 2015). The minor effect may have been related to the limited degeneration grade in this model. As this gel was proven to be suitable for delivery and transfection of siRNA, very specific inhibition of various other factors through RNAi-mediated gene silencing is also envisaged (Willems et al., 2015).

\section{Solid synthetic biomaterials}

Various studies were performed using PLGA as delivery system. Nanostructured composites of PLGA microspheres loaded with dexamethasone and FGF-embedded heparin/poly(l-lysine) nanoparticles effectively induced chondrogenic differentiation of MSCs seeded on the microspheres (Liang et al., 2012). In vivo, in a rat model of puncture-induced IVD degeneration, adipose-derived stem cells were seeded on a similar drug delivery system of PLGA microspheres loaded with dexamethasone and TGF- $\beta 3$, with a release for at least $28 \mathrm{~d}$ in vitro. At 24-weeks follow up, IVDs treated with the delivery system alone and the delivery system seeded with cells, regained height and restored proteoglycan content compared to untreated controls, although not to the levels of healthy controls (Liang et al., 2013). Likewise, PLGA microspheres releasing growth differentiation factor 5 (GDF-5) over the course of 42 days improved IVD height, GAG and DNA content of treated discs compared to punctured untreated 

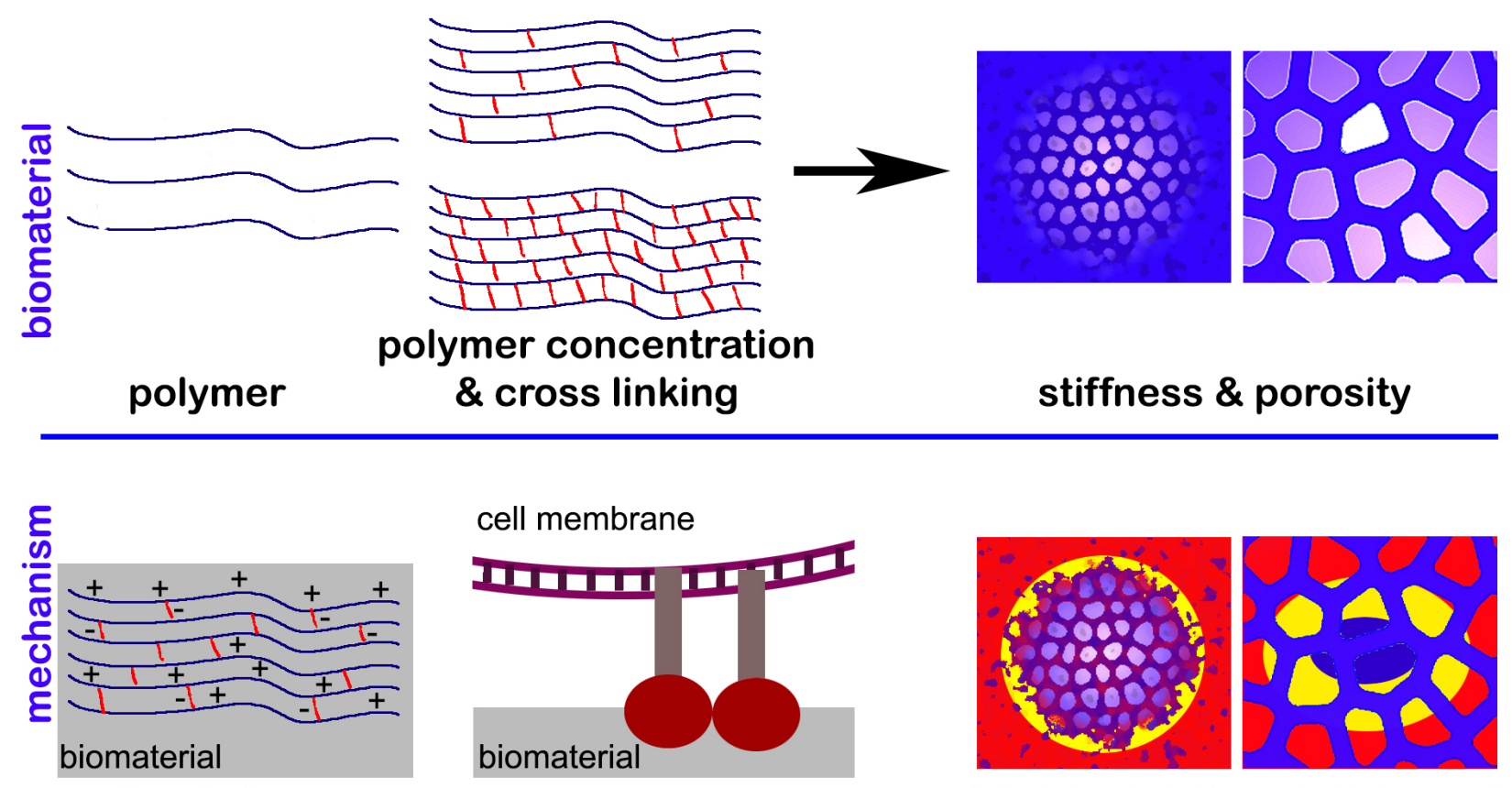

fixed charge density adhesion
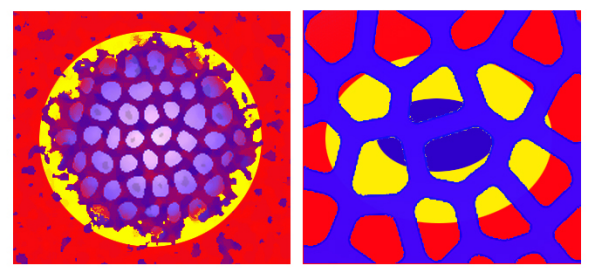

$20 \%$

$\mathrm{O}_{2}$ tension

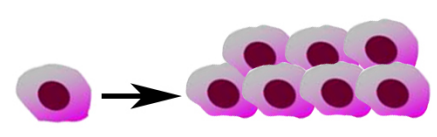

cell proliferation

Fig. 4. Scaffold characteristics determining cell behaviour and tissue regeneration. Biomaterial properties affect cell behaviour through various mechanisms, thereby determining the differentiation pathways chosen and the proliferative response.

IVDs in a rat tail degeneration model (Yan et al., 2013). However, no single intra-discal application of growth factors was included as comparator in these studies.

Release of interleukin-1 receptor antagonist (IL-1ra) from PLGA microspheres was shown to attenuate the degradation induced by IL- $1 \beta$ in agarose-bovine NP cell constructs. The inhibitory effects on inflammation were most obvious during the first week of culture. Strikingly, although beyond 3 days of release proteoglycan content was not restored further, the biomechanical properties of the constructs were restored to control levels (Gorth et al., 2012).

Altogether, it appears that the concept of employing biomaterials for the sustained delivery of agents in IVD regeneration is just emerging. However, local prolonged exposure to factors modulating regeneration and degeneration holds great promise by reduction of systemic side effects and increasing effectivity.

\section{Towards rational design of biomaterials for IVD regeneration}

The response of cells to biomaterials depends on a complex set of chemical, physicochemical and physical parameters (Fig. 4). Understanding the intrinsic effects of biomaterials on incorporated cells and addressing these in focussed biomaterial studies is likely to enhance the search for the most effective material.

\section{Extracellular matrix-cell interaction}

Mesenchymal cell attachment to its surrounding material strongly affects its behaviour. Most of this attachment will be mediated by the ECM binding integrins present on the cell surface. The ECM motifs are either provided directly by the material used (gelatin, collagen, fibronectin), by serum adhesion proteins (Kobayashi et al., 2005; Yang et al., 2013; Dodo et al., 2013), or early deposition of ECM by the cells themselves (Pearlstein et al., 1980; Desai et 
al., 2014; Jin et al., 2007; Sharma et al., 2012; Xu et al., 2013). Integrin-mediated cell-matrix binding not only affects chondrogenic cell survival and proliferation in vitro and in vivo (Gilchrist et al., 2007; Loeser, 2014), but is also involved in cell differentiation by regulating the response to materials with different mechanical properties. High stiffness results in osteogenesis by MSCs (Huebsch et al., 2010), most likely through the availability of ECM binding sites (Trappmann et al., 2012) and a process involving stress fibre formation. Inhibition of this pathway favours adipogenic or chondrogenic differentiation (Dupont et al., 2011; Khetan et al., 2013; McBeath et al., 2004; Xu et al., 2014), probably co-regulated by growth factor signalling (Park et al., 2011a). In addition to integrin receptors, several other cell-material receptors have been described, of which the hyaluronic acid receptor CD44 also appears to mediate chondrogenic differentiation and regeneration by hMSCs (Bian et al., 2013; Wu et al., 2013), although HA binding appears not to be involved in sensing stiffness (Khetan et al., 2013). Toll like receptor (TLR) signalling, originally identified in immune cells, may affect MSC and chondrocyte behaviour by enhancing cytokine production (Shokouhi et al., 2010; Campo et al., 2012; Sillat et al., 2013; Tsuchida et al., 2013), although the ensuing effect on regeneration was not studied yet.

\section{Hypoxia, porosity and fixed charge density}

In terms of physical and physicochemical properties affecting cell behaviour, hypoxia is known to enhance chondrocyte redifferentiation through hypoxia-inducible factor 1alpha (HIF1 $\alpha$ ) expression and GAG deposition by MSCs (Duval et al., 2009; Buckley et al., 2012). Fixed charge density has been shown to above neutral values inhibit chondrocyte redifferentiation on top of hydrogels (Yang et al., 2010).

\section{Towards efficient biomaterial design}

All in all many biomaterial-related properties are known to affect the cell response, of which many cannot be fully dissected from each other. Porosity will for example simultaneously affect hypoxia, nutrient diffusion, and attachment and stress fibre formation. The relative contribution of these properties in determining cell behaviour is unclear and will in addition depend on cell type. It should also be borne in mind that crosslinking of natural biomaterials, such as methacrylation of HA or crosslinking of gelatin, to enhance biomechanical properties may compromise degradability and biocompatibility.

A promising approach towards efficient design of materials for IVD cell regeneration may entail the use of biomaterial arrays. 3D high throughput arrays of over 1000 different biomaterials have been applied to study proliferation and differentiation, until now mainly of MSCs and preosteoblasts (Dolahatshai-Pirouz 2014; Chatterjee 2010). Biomaterial arrays not only can be used to determine the optimal response, in a widely varying array of biomaterials, but also in arrays of very similar polymers to determine essential chemical characteristics. Testing of material blends is also most likely possible, though not undertaken as yet. In addition to measuring cell differentiation and proliferation, the readout of biomaterial screens can also be biomechanical (Tweedie $e t$ al., 2005), which will be crucial as the type and magnitude of biomechanical input to the cell-biomaterial construct, in particular the relation between hydrostatic and shear stress, will affect differentiation (Carter et al., 2004; NeidlingerWilke et al., 2009). Final identification of biomaterials or their physicochemical characteristics as regenerative will be achieved by automated multifactorial analysis of the results.

Although the design of these arrays will be a task for skilled engineers, defining the readout parameters and using the right cell type will be the responsibility of the IVD biologist. Here, a key challenge may lie in outlining IVD cell differentiation and regeneration, which until now has mostly been defined in terms of chondrogenic ECM production, which in particular will not distinguish between cartilage and nucleus pulposus tissue. Recently, a consensus paper was published defining the healthy NP cell by several protein markers and functional characteristics (Risbud et al., 2015). As hardly any of these markers are present both exclusively and exhaustively in all NP cells, the ratio of aggrecan/collagen II may possibly be the most reliable parameter to relatively easily and safely define NP-like regeneration. This ratio has been shown to be always above 5:1 in the NP, even around 25:1 in healthy tissue, whereas for cartilage this never exceeds $3: 1$. Other screen readouts, for some of which other cell types will be used, may be anti-inflammatory, anti-angiogenic and anti-neurogenic properties, given the suggested association between low back pain and nerve ingrowth towards the centre of the NP. Finally, as different stages of IVD degeneration may require different types of biomaterials, the use of cells from different degeneration stages in the biomaterial screens will be required.

Importantly, in the course of validation, ex vivo and in vivo models in different stages of degeneration will be a prerequisite to match biomaterials to degeneration grade. In addition to the medium-throughput screening of in vivo biocompatibility already available (Oliveira et al., 2014) further validation in ex vivo IVD organ culture models, preferably of clinically relevant sizes, may allow for standardised and reliable testing before finally using in vivo models (Hudson et al., 2013).

\section{Concluding Remarks}

In the $21^{\text {st }}$ century, regenerative medicine will become one of the most important strategies of treating disease in general and IVD degeneration in particular. Biomaterials may serve a crucial role in this approach because they provide immediate mechanical support and instruct cells in the IVD to differentiate and produce new extracellular matrix.

The advantages of natural materials include established degradation pathways, biocompatibility and safety. In general, they provide more favourable environments for cell proliferation and regeneration. However, the material properties of natural polymers are difficult to control, and the manufacturing processes are expensive 
for recombinant proteins, or are based on animal tissues, with concomitant regulatory issues. Synthetic biomaterials allow for easy and reproducible manufacturing, while their chemical properties are simpler to adjust. However, the byproducts of degradation are in some cases harmful and the interaction with cells often limited. In practice, most of the materials mentioned have been tested in mixtures, because this allows blending of properties from each material, thereby improving biodegradability, biocompatibility or biomechanical functionality.

On the whole, the application of biomaterials for regeneration of the IVD appears, until now, to have been mainly directed by intuition and/or mere availability. This has likely not enhanced progress in this area, as illustrated by the fact that, to date, only one hydrogel has made it into a clinical trial. Advancement of the field towards more effective design of biomaterials may be provided by high throughput screening of biomaterials, in which several characteristics of biomaterials are related to their regenerative effects. However, as this will likely involve a substantial lag time in development, an alternative route may possibly lie in extensive comparative studies carried out at several IVD research laboratories, leading to the identification of some kind of reference biomaterials for NP and AF regeneration. Standardisation of characterisation and testing, including relevant biomechanical properties, biocompatibility and regenerative responses, would provide a major advantage here.

Finally, the clinical application of biomaterials may require some further research into the surgical techniques needed. Already, large sized needle injection of large volumes of fluid (Chee et al., 2014) was suggested to accelerate IVD degeneration (Carragee et al., 2009). Therefore, materials for NP regeneration are preferably injectable, using needles with small diameters, thereby excluding solid scaffolds and limiting the injectable volume. Alternatively, an approach through the endplate may be considered. AF regeneration may on the other hand be more feasible with solid scaffolds that at the same time withstand the tensile stresses and are capable of firmly adhering to the native tissue.

\section{Acknowledgements}

Authors gratefully acknowledge funding as part of the Project P2.01 IDiDAS of the research program of the BioMedical Materials Institute, co-funded by the Dutch Ministry of Economic Affairs, Agriculture and Innovation. In addition, the financial contribution of the Dutch Arthritis Foundation (LLP12 and LLP22) and the Dutch Government to the Netherlands Institute for Regenerative Medicine (NIRM, grant $n^{\circ}$ FES0908) is acknowledged. We wish to confirm that there are no known conflicts of interest associated with this publication and there has been no significant financial support for this work that could have influenced its outcome.

\section{References}

Acosta FL, Metz L, Adkisson HD, Liu J, CarruthersLiebenberg E, Milliman C, Maloney M, Lotz JC (2011) Porcine intervertebral disc repair using allogeneic juvenile articular chondrocytes or mesenchymal stem cells. Tissue Eng Part A 17: 3045-3055.

Adams MA, Lama P, Zehra U, Dolan P (2014) Why do some intervertebral discs degenerate, when others (in the same spine) do not? Clin Anat 28: 195-204.

Agrawal CM, Athanasiou KA (1996) Technique to control $\mathrm{pH}$ in vicinity of biodegrading PLA-PGA implants. J Biomed Mater Res 38: 105-114.

Agrawal CM, Ray RB (2001) Biodegradable polymeric scaffolds for musculoskeletal tissue engineering. J Biomed Mater Res 55: 141-150.

Ahmed TAE, Dare EV, Hincke M (2008) Fibrin: a versatile scaffold for tissue engineering applications. Tissue Eng Part B Rev 14: 199-215.

Anderson DG, Risbud MV, Shapiro IM, Vaccaro AR, Albert TJ (2005) Cell-based therapy for disc repair. Spine J 5: 297S-303S.

Ashley GW, Henise J, Reid R, Santi DV (2013) Hydrogel drug delivery system with predictable and tunable drug release and degradation rates. Proc Natl Acad Sci USA 110: 2318-2323.

Attia M, Santerre JP, Kandel RA (2011) The response of annulus fibrosus cell to fibronectin-coated nanofibrous polyurethane-anionic dihydroxyoligomer scaffolds. Biomaterials 32: 450-460.

Badylak SF, Tullius R, Kokini K, Shelbourne KD, Klootwyk T, Voytik SL, Kraine MR, Simmons C (1995) The use of xenogeneic small intestinal submucosa as a biomaterial for Achilles tendon repair in a dog model. J Biomed Mater Res 29: 977-985.

Badylak SF, Freytes DO, Gilbert TW (2009) Extracellular matrix as a biological scaffold material: Structure and function. Acta Biomater 5: 1-13.

Battie MC, Videman T (2006) Lumbar disc degeneration: epidemiology and genetics. J Bone Joint Surg Am 88 Suppl 2: 3-9.

Benoit DSW, Anseth KS (2005) The effect on osteoblast function of colocalized RGD and PHSRN epitopes on PEG surfaces. Biomaterials 26: 5209-5220.

Benz K, Stippich C, Osswald C, Gaissmaier C, Lembert N, Badke A, Steck E, Aicher WK, Mollenhauer JA (2012a) Rheological and biological properties of a hydrogel support for cells intended for intervertebral disc repair. BMC Musculoskelet Disord 13: 54.

Benz K, Stippich C, Fischer L, Möhl K, Weber K, Lang J, Steffen F, Beintner B, Gaissmaier C, Mollenhauer $\mathrm{J}$ (2012b) Intervertebral disc cell- and hydrogel-supported and spontaneous intervertebral disc repair in nucleotomized sheep. Eur Spine J 21: 1758-1768.

Bertolo A, Mehr M, Aebli N, Baur M, Ferguson SJ, Stoyanov JV (2012) Influence of different commercial scaffolds on the in vitro differentiation of human mesenchymal stem cells to nucleus pulposus-like cells. Eur Spine J 21 Suppl 6: S826-838.

Bian L, Guvendiren M, Mauck RL, Burdick JA (2013) Hydrogels that mimic developmentally relevant matrix and 
$\mathrm{N}$-cadherin interactions enhance MSC chondrogenesis. Proc Natl Acad Sci USA 110: 10117-10122.

Blanquer SB, Sharifi S, Grijpma DW (2012) Development of poly(trimethylene carbonate) network implants for annulus fibrosus tissue engineering. J Appl Biomater Funct Mater 10: 177-184.

Bron JL, Koenderink GH, Everts V, Smit TH (2009) Rheological characterization of the nucleus pulposus and dense collagen scaffolds intended for functional replacement. J Orthop Res 27: 620-626.

Bron JL, Vonk LA, Smit TH, Koenderink GH (2011) Engineering alginate for intervertebral disc repair. J Mech Behav Biomed Mater 4: 1196-1205.

Bron JL, Mulder HW, Vonk LA, Doulabi BZ, Oudhoff MJ, Smit TH (2012) Migration of intervertebral disc cells into dense collagen scaffolds intended for functional replacement. J Mater Sci Mater Med 23: 813-821.

Buckley CT, Meyer EG, Kelly DJ (2012) The influence of construct scale on the composition and functional properties of cartilaginous tissues engineered using bone marrow-derived mesenchymal stem cells. Tissue Eng Part A 18: 382-396.

Campo G, Avenoso A, D'Ascola A, Prestipino V, Scuruchi M, Nastasi G, Calatroni A, Campo S (2012) Hyaluronan differently modulates TLR-4 and the inflammatory response in mouse chondrocytes. Biofactors 38: $69-76$.

Carragee EJ, Don AS, Hurwitz EL, Cuellar JM, Carrino JA, Carrino J, Herzog R (2009) Does discography cause accelerated progression of degeneration changes in the lumbar disc: a ten-year matched cohort study. Spine 34: 2338-2345.

Carter DR, Beaupré GS, Wong M, Smith RL, Andriacchi TP, Schurman DJ (2004) The mechanobiology of articular cartilage development and degeneration. Clin Orthop Relat Res 427: S69-S77.

Cen L, Liu W, Cui L, Zhang W, Cao Y (2008) Collagen tissue engineering: development of novel biomaterials and applications. Pediatr Res. 63: 492-496.

Chan SC, Gantenbein-Ritter B (2012) Intervertebral disc regeneration or repair with biomaterials and stem cell therapy - feasible or fiction? Swiss Med Wkly 142: w13598.

Chang G, Kim HJ, Vunjak-Novakovic G, Kaplan DL, Kandel R (2010) Enhancing annulus fibrosus tissue formation in porous silk scaffolds. J Biomed Mater Res A 92: 43-51.

Chatterjee K, Lin-Gibson S, Wallace WE, Parekh SH, Lee YJ, Cicerone MT, Young MF, Simon CG Jr (2010) The effect of 3D hydrogel scaffold modulus on osteoblast differentiation and mineralization revealed by combinatorial screening. Biomaterials 31: 5051-5062.

Chee A V, Ren J, Lenart BA, Chen E-Y, Zhang Y, An HS (2014) Cytotoxicity of local anesthetics and nonionic contrast agents on bovine intervertebral disc cells cultured in a three-dimensional culture system. Spine J 14: 491-498.

Chen J, Yan W, Setton LA (2004) Static compression induces zonal-specific changes in gene expression for extracellular matrix and cytoskeletal proteins in intervertebral disc cells in vitro. Matrix Biol 22: 573-583.
Chen YC, Su WY, Yang SH, Gefen A, Lin FH (2013) In situ forming hydrogels composed of oxidized high molecular weight hyaluronic acid and gelatin for nucleus pulposus regeneration. Acta Biomater 9: 5181-5193.

Cheng YH, Yang SH, Su WY, Chen YC, Yang KC, Cheng WT, Wu SC, Lin FH (2010) Thermosensitive chitosan-gelatin-glycerol phosphate hydrogels as a cell carrier for nucleus pulposus regeneration: an in vitro study. Tissue Eng A 16: 695-703.

Cheng YH, Yang SH, Lin FH (2011) Thermosensitive chitosan-gelatin-glycerol phosphate hydrogel as a controlled release system of ferulic acid for nucleus pulposus regeneration. Biomaterials 32: 6953-6961.

Cheng YH, Yang SH, Liu CC, Gefen A, Lin FH (2013) Thermosensitive hydrogel made of ferulic acid-gelatin and chitosan glycerophosphate. Carbohydr Polym 92: 15121519.

Chou AI, Nicoll SB (2009) Characterization of photocrosslinked alginate hydrogels for nucleus pulposus cell encapsulation. J Biomed Mater Res A 91: 187-194.

Chou AI, Akintoye SO, Nicoll SB (2009) Photocrosslinked alginate hydrogels support enhanced matrix accumulation by nucleus pulposus cells in vivo. Osteoarthritis Cartilage 17: 1377-1384.

Chung C, Beecham M, Mauck RL, Burdick JA (2009) The influence of degradation characteristics of hyaluronic acid hydrogels on in vitro neocartilage formation by mesenchymal stem cells. Biomaterials 30: 4287-4296.

Cloyd JM, Malhotra NR, Weng L, Chen W, Mauck RL, Elliott DM (2007) Material properties in unconfined compression of human nucleus pulposus, injectable hyaluronic acid-based hydrogels and tissue engineering scaffolds. Eur Spine J 16: 1892-1898.

Collin EC, Grad S, Zeugolis DI, Vinatier CS, Clouet JR, Guicheux JJ, Weiss P, Alini M, Pandit AS (2011) An injectable vehicle for nucleus pulposus cell-based therapy. Biomaterials 32: 2862-2870

Collins MN, Birkinshaw C (2013) Hyaluronic acid based scaffolds for tissue engineerin - a review. Carbohydr Polym 92: 1262-1279.

Colombini A, Ceriani C, Banfi G, Brayda-Bruno M, Moretti M (2014) Fibrin in intervertebral disc tissue engineering. Tissue Eng Part B Rev 20: 713-721.

Cortes DH, Jacobs NT, Delucca JF, Elliott DM (2014) Elastic, permeability and swelling properties of human intervertebral disc tissues: A benchmark for tissue engineering. J Biomech 47: 2088-2094.

Crevensten G, Walsh AJ, Ananthakrishnan D, Page P, Wahba GM, Lotz JC, Berven S (2004) Intervertebral disc cell therapy for regeneration: mesenchymal stem cell implantation in rat intervertebral discs. Ann Biomed Eng 32: $430-434$

Dahl MC, Ahrens M, Sherman JE, Martz EO (2010) The restoration of lumbar intervertebral disc load distribution: a comparison of three nucleus replacement technologies. Spine 35: 1445-1453.

Dai T, Tanaka M, Huang YY, Hamblin MR (2011) Chitosan preparations for wounds and burns: antimicrobial and wound-healing effects. Expert Rev Anti Infect Ther 9: 857-879. 
Danhier F, Ansorena E, Silva JM, Coco R, Breton A Le, Preat V (2012) PLGA-based nanoparticles: an overview of biomedical applications. J Control Release 161: 505-522.

Darwis D, Stasica P, Razzak MT, Rosiak JM (2002) Characterization of poly(vinyl alcohol) hydrogel for prosthetic intervertebral disc nucleus. Radiat Phys Chem 63: $539-542$.

Dash TK, Konkimalla VB (2012) Poly-€-caprolactone based formulations for drug delivery and tissue engineering: A review. J Control Release 158: 15-33.

Dejardin LM, Arnoczky SP, Ewers BJ, Haut RC, Clarke RB (2001) Tissue-engineered rotator cuff tendon using porcine small intestine submucosa. Histologic and mechanical evaluation in dogs. Am J Sports Med 29: $175-$ 184.

Desai VD, Hsia HC, Schwarzbauer JE (2014) Reversible modulation of myofibroblast differentiation in adipose-derived mesenchymal stem cells. PLoS One 9: e86865.

Diederichs S, Baral K, Tanner M, Richter W (2012) Interplay between local versus soluble transforming growth factor-beta and fibrin scaffolds: role of cells and impact on human mesenchymal stem cell chondrogenesis. Tissue Eng Part A 18: 1140-1150.

Di Martino A, Sittinger M, Risbud MV (2005) Chitosan: a versatile biopolymer for orthopaedic tissueengineering. Biomaterials 26: 5983-5990.

Ding AG, Schwendeman SP (2008) Acidic microclimate $\mathrm{pH}$ distribution in PLGA microspheres monitored by confocal laser scanning microscopy. Pharm Res 25: 2041 2052.

Dodo CG, Senna PM, Custodio W, Paes Leme AF, Del Bel Cury AA (2013) Proteome analysis of the plasma protein layer adsorbed to a rough titanium surface. Biofouling 29: 549-557.

Dolatshahi-Pirouz A, Nikkhah M, Gaharwar AK, Hashmi B, Guermani E, Aliabadi H, Camci-Unal G, Ferrante T, Foss M, Ingber DE, Khademhosseini A (2014) A combinatorial cell-laden gel microarray for inducing osteogenic differentiation of human mesenchymal stem cells. Sci Rep 4: 3896.

Drira Z, Yadavalli VK (2013) Nanomechanical measurements of polyethylene glycol hydrogels using atomic force microscopy. J Mech Behav Biomed Mater 18: $20-28$.

Dupont S, Morsut L, Aragona M, Enzo E, Giulitti S, Cordenonsi M, Zanconato F, Le Digabel J, Forcato M, Bicciato S, Elvassore N, Piccolo S (2011) Role of YAP/ TAZ in mechanotransduction. Nature 474: 179-183.

Duval E, Leclercq S, Elissalde J-M, Demoor M, Galéra P, Boumédiene K (2009) Hypoxia-inducible factor 1alpha inhibits the fibroblast-like markers type I and type III collagen during hypoxia-induced chondrocyte redifferentiation: hypoxia not only induces type II collagen and aggrecan, but it also inhibits type I and type III collagen. Arthritis Rheum 60: 3038-3048.

El-Amin SF, Lu HH, Khan Y, Burems J, Mitchell J, Tuan RS, Laurencin CT (2003) Extracellular matrix production by human osteoblasts cultured on biodegradable polymers applicable for tissue engineering. Biomaterials 24: 1213-1221.
Ella V, Kellomaki M, Tormala P (2005) In vitro properties of PLLA screws and novel bioabsorbable implant with elastic nucleus to replace intervertebral disc. J. Mater. Sci. Med. 16: 655-662.

Endres M, Abbushi A, Thomale UW, Cabraja M, Kroppenstedt SN, Morawietz L, Casalis PA, Zenclussen ML, Lemke AJ, Horn P, Kaps C, Woiciechowsky C (2010) Intervertebral disc regeneration after implantation of a cellfree bioresorbable implant in a rabbit disc degeneration model. Biomaterials 31: 5836-5841.

Erickson IE, Huang AH, Sengupta S, Kestle S, Burdick JA, Mauck RL (2009) Macromer density influences mesenchymal stem cell chondrogenesis and maturation in photocrosslinked hyaluronic acid hydrogels. Osteoarthritis Cartilage 17: 1639-1648.

Etebar S, Cahill DW (1999) Risk factors for adjacentsegment failure following lumbar fixation with rigid instrumentation for degenerative instability. J Neurosurg 90: $163-169$.

Eyrich D, Brandl F, Appel B, Wiese H, Maier G, Wenzel M, Staudenmaier R, Goepferich A, Blunk T (2007) Long-term stable fibrin gels for cartilage engineering. Biomaterials 28: 55-65.

Feng G, Jin X, Hu J, Ma H, Gupte MJ, Liu H, Ma PX (2011) Effects of hypoxia and scaffold architecture on rabbit mesenchymal stem cell differentiation towards a nucleus pulposus-like phenotype. Biomaterials 32: 81828189.

Ferreira AM, Gentile P, Chiono V, Ciardelli G (2012) Collagen for bone tissue regeneration. Acta Biomater 8: 3191-3200.

Foss BL, Maxwell TW, Deng Y(2014)Chondroprotective supplementation promotes the mechanical properties of injectable scaffold for human nucleus pulposus tissue engineering. J Mech Behav Biomed Mater 29: 56-67.

Francisco AT, Hwang PY, Jeong CG, Jing L, Chen J, Setton LA (2014) Photocrosslinkable lamininfunctionalized polyethylene glycol hydrogel for intervertebral disc regeneration. Acta Biomater 10: 11021111.

Frith JE, Cameron AR, Menzies DJ, Ghosh P, Whitehead DL, Gronthos S, Zannettino AC, CooperWhite JJ (2013) An injectable hydrogel incorporating mesenchymal precursor cells and pentosan polysulphate for intervertebral disc regeneration. Biomaterials 34: 94309440 .

Ganey T, Hutton WC, Moseley T, Hedrick M, Meisel H-J (2009) Intervertebral disc repair using adipose tissuederived stem and regenerative cells: experiments in a canine model. Spine 34: 2297-2304.

Ghosh P, Moore R, Vernon-Roberts B, Goldschlager T, Pascoe D, Zannettino A, Gronthos S, Itescu S (2012) Immunoselected STRO-3+ mesenchymal precursor cells and restoration of the extracellular matrix of degenerate intervertebral discs. J Neurosurg Spine 16: 479-488.

Gilchrist CL, Chen J, Richardson WJ, Loeser RF, Setton LA, Engineering B, Hall H (2007) Functional integrin subunits regulating cell - Matrix interactions in the intervertebral disc. J Orthop Res 25: 829-840.

Gloria A, Causa F, De Santis R, Netti PA, Ambrosio L (2007) Dynamic-mechanical properties of a novel 
composite intervertebral disc prosthesis. J Mater Sci Med 18: $2159-2165$.

Gorth DJ, Mauck RL, Chiaro JA, Mohanraj B, Hebela NM, Dodge GR, Elliott DM, Smith LJ (2012) IL-1ra delivered from poly(lactic-co-glycolic acid) microspheres attenuates IL-1beta-mediated degradation of nucleus pulposus in vitro. Arthritis Res Ther 14: R179.

Gruber HE, Hoelscher GL, Leslie K, Ingram JA, Hanley EN Jr (2006) Three-dimensional culture of human disc cells within agarose or a collagen sponge: assessment of proteoglycan production. Biomaterials 27: 371-376.

Guillaume O, Naqvi SM, Lennon K, Buckley CT (2015) Enhancing cell migration in shape-memory alginate-collagen composite scaffolds: In vitro and ex vivo assessment for intervertebral disc repair. J Biomater Appl 29: 1230-1246.

Guo JF, Jourdian GW, MacCallum DK (1989) Culture and growth characteristics of chondrocytes encapsulated in alginate beads. Connect Tissue Res 19: 277-297.

Gupta A, Bhat S, Jagdale PR, Chaudhari BP, Lidgren L, Gupta KC, Kumar A (2014) Evaluation of threedimensional chitosan-agarose-gelatin cryogel scaffold for the repair of subchondral cartilage defects: an in vivo study in a rabbit model. Tissue Eng Part A 20: 3101-3111.

Heathfield SK, Le Maitre CL, Hoyland JA (2008) Caveolin-1 expression and stress-induced premature senescence in human intervertebral disc degeneration. Arthritis Res Ther 10: R87.

Hegewald AA, Enz A, Endres M, Sittinger M, Woiciechowsky C, Thome C, Kaps C (2010) Engineering of polymer-based grafts with cells derived from human nucleus pulposus tissue of the lumbar spine. J Tissue Eng Regen Med 5: 275-282.

Helgeson MD, Bevevino AJ, Hilibrand AS (2013) Update on the evidence for adjacent segment degeneration and disease. Spine J 13: 342-351.

Hern DL, Hubbell JA (1998) Incorporation of adhesion peptides into nonadhesive hydrogels useful for tissue resurfacing. J Biomed Mater Res 39: 266-276.

Higashino K, Hamasaki T, Kim JH, Okada M, Yoon ST, Boden SD, Hutton WC (2010) Do the adjacent level intervertebral discs degenerate after a lumbar spinal fusion? An experimental study using a rabbit model. Spine 35: E1144-1152.

Ho STB, Cool SM, Hui JH, Hutmacher DW (2010) The influence of fibrin based hydrogels on the chondrogenic differentiation of human bone marrow stromal cells. Biomaterials 31: 38-47.

Hu J, Chen B, Guo F, Du J, Gu P, Lin X, Yang W, Zhang H, Lu M, Huang Y, Xu G (2012) Injectable silk fibroin/ polyurethane composite hydrogel for nucleus pulposus replacement. J Mater Sci Med 23: 711-722.

Huang Y, Onyeri S, Siewe M, Moshfeghian A, Madihally SV (2005) In vitro characterization of chitosangelatin scaffolds for tissue engineering. Biomaterials 26: 7616-7627.

Hudson KD, Alimi M, Grunert P, Härtl R, Bonassar LJ (2013) Recent advances in biological therapies for disc degeneration: tissue engineering of the annulus fibrosus, nucleus pulposus and whole intervertebral discs. Curr Opin Biotechnol 24: 872-879.
Huebsch N, Arany R, Mao A, D S, Ali O, Bencherif SA, Reveira-Feliciano J, Mooney D (2010) Harnessing traction-mediated manipulation of the cell-matrix interface to control stem cell fate. Nat Mater 9: 518-526.

Hung K-C, Tseng C-S, Hsu S-H (2014) Synthesis and $3 \mathrm{D}$ printing of biodegradable polyurethane elastomer by a water-based process for cartilage tissue engineering applications. Adv Healthc Mater 3: 1578-1587.

Hunt NC, Grover LM (2010) Cell encapsulation using biopolymer gels for regenerative medicine. Biotechnol Lett 32: 733-742.

Hunter CJ, Matyas JR, Duncan NA (2004) Cytomorphology of notochordal and chondrocytic cells from the nucleus pulposus: a species comparison. J Anat 205: 357-362.

Hutton WC, Murakami H, Li J, Elmer WA, Yoon ST, Minamide A, Akamaru T, Tomita K (2004) The effect of blocking a nutritional pathway to the intervertebral disc in the dog model. J Spinal Disord Tech 17: 53-63.

Iatridis JC, Weidenbaum M, Setton LA, Mow VC (1996) Is the nucleus pulposus a solid or a fluid? Mechanical behaviors of the nucleus pulposus of the human intervertebral disc. Spine 21: 1174-1184.

Iatridis JC, Mente PL, Stokes IA, Aronsson DD, Alini M (1999) Compression-induced changes in intervertebral disc properties in a rat tail model. Spine 24: 996-1002.

Isaacs JL, Vresilovic E, Sarkar S, Marcolongo M (2014) Role of biomolecules on annulus fibrosus micromechanics: Effect of enzymatic digestion on elastic and failure properties. J Mech Behav Biomed Mater 40C: 75-84.

Iwasaki N, Yamane S-T, Majima T, Kasahara Y, Minami A, Harada K, Nonaka S, Maekawa N, Tamura H, Tokura S, Shiono M, Monde K, Nishimura S (2004) Feasibility of polysaccharide hybrid materials for scaffolds in cartilage tissue engineering: evaluation of chondrocyte adhesion to polyion complex fibers prepared from alginate and chitosan. Biomacromolecules 5: 828-833.

Jacobs WCH, Rubinstein SM, Koes B, van Tulder MW, Peul WC (2013) Evidence for surgery in degenerative lumbar spine disorders. Best Pract Res Clin Rheumatol 27: 673-684.

Jeong CG, Francisco AT, Niu Z, Mancino RL, Craig SL, Setton LA (2014) Screening of hyaluronic acidpoly(ethylene glycol) composite hydrogels to support intervertebral disc cell biosynthesis using artificial neural network analysis. Acta Biomater 10: 3421-3430.

Jin E-J, Choi Y-A, Kyun Park E, Bang O-S, Kang S-S (2007) MMP-2 functions as a negative regulator of chondrogenic cell condensation via down-regulation of the FAK-integrin beta1 interaction. Dev Biol 308: 474-484.

Jonsson L, Gatzinsky V, Jennische E, Johansson C, Nannmark U, Friberg LG (2011) Piglet model for studying esophageal regrowth after resection and interposition of a silicone stented small intestinal submucosa tube. Eur Surg Res 46: 169-179.

Joshi A, Fussell G, Thomas J, Hsuan A, Lowman A, Karduna A, Vresilovic E, Marcolongo M (2006) Functional compressive mechanics of a PVA/PVP nucleus pulposus replacement. Biomaterials 27: 176-184.

Kenne L, Gohil S, Nilsson EM, Karlsson A, Ericsson D, Kenne AH, Nord LI (2013) Modification and cross-linking 
parameters in hyaluronic acid hydrogels - definitions and analytical methods. Carbohydr Polym 91: 410-418.

Khetan S, Guvendiren M, Legant WR, Cohen DM, Christopher S, Burdick JA (2013) Degradation-mediated cellular traction directs stem cell fate in covalently crosslinked three-dimensional hydrogels. Nat Mater 12: 458-465.

Kim JH, Deasy BM, Seo HY, Studer RK, Vo NV, Georgescu HI, Sowa GA, Kang JD (2009) Differentiation of intervertebral notochordal cells through live automated cell imaging system in vitro. Spine 34: 2486-2493.

Kim IL, Mauck RL, Burdick JA (2011) Hydrogel design for cartilage tissue engineering: a case study with hyaluronic acid. Biomaterials 32: 8771-8782.

Kim HY, Kim HN, Lee SJ, Song JE, Kwon SY, Chung JW, Lee D, Khang G (2014a) Effect of pore sizes of PLGA scaffolds on mechanical properties and cell behaviour for nucleus pulposus regeneration in vivo. J Tissue Eng Regen Med: doi: 10.1002/term.1856.

Kim SH, Song JE, Lee D, Khang G (2014b) Development of poly(lactide-co-glycolide) scaffoldimpregnated small intestinal submucosa with pores that stimulate extracellular matrix production in disc regeneration. J Tissue Eng Regen Med 8: 279-290.

Kobayashi T, Soegiarto DW, Yang Y, Lanske B, Schipani E, Mcmahon AP, Kronenberg HM (2005) Indian hedgehog stimulates periarticular chondrocyte differentiation to regulate growth plate length independently of PTHrP. J Clin Invest 115: 1734-1742.

Koepsell L, Remund T, Bao J, Neufeld D, Fong H, Deng Y (2011a) Tissue engineering of annulus fibrosus using electrospun fibrous scaffolds with aligned polycaprolactone fibers. J Biomed Mater Res A 99: 564-575.

Koepsell L, Zhang L, Neufeld D, Fong H, Deng Y (2011b) Electrospun nanofibrous polycaprolactone scaffolds for tissue engineering of annulus fibrosus. Macromol Biosci 11: 391-399.

Kogan G, Soltes L, Stern R, Gemeiner P (2007) Hyaluronic acid: a natural biopolymer with a broad range of biomedical and industrial applications. Biotechnol Lett 29: 17-25.

Kota DJ, Prabhakara KS, Cox CS, Olson SD (2014) MSCs and hyaluronan: Sticking together for new therapeutic potential? Int J Biochem Cell Biol 55: 1-10.

Lai P, Daear W, Löbenberg R, Prenner EJ (2014) Overview of the preparation of organic polymeric nanoparticles for drug delivery based on gelatine, chitosan, poly(d,1-lactide-co-glycolic acid) and polyalkylcyanoacrylate. Colloids Surf B Biointerfaces 118: $154-163$.

Larsen B, Haug A (1971) Biosynthesis of alginate. 1. Composition and structure of alginate produced by Azotobacter vinelandii (Lipman). Carbohydr Res 17: 287 296.

Lazebnik M, Singh M, Glatt P, Friis LA, Berkland CJ, Detamore MS (2011) Biomimetic method for combining the nucleus pulposus and annulus fibrosus for intervertebral disc tissue engineering. J Tissue Eng Regen Med 5: e179187.

Ledet EH, Jeshuran W, Glennon JC, Shaffrey C, De Deyne P, Belden C, Kallakury B, Carl AL (2009) Small intestinal submucosa for annular defect closure: long-term response in an in vivo sheep model. Spine 34: 1457-1463.

Lee KY, Mooney DJ (2012) Alginate: properties and biomedical applications. Prog Polym Sci 37: 106-126.

Lee CH, Singla A, Lee Y (2001) Biomedical applications of collagen. Int J Pharm 221: 1-22.

Leone G, Torricelli P, Chiumiento A, Facchini A, Barbucci R (2008) Amidic alginate hydrogel for nucleus pulposus replacement. J Biomed Mater Res A 84: 391-401.

Le Visage C, Yang SH, Kadakia L, Sieber AN, Kostuik JP, Leong KW (2006) Small intestinal submucosa as a potential bioscaffold for intervertebral disc regeneration. Spine 31: 2423-2430.

Li WJ, Tuli R, Okafor C, Derfoul A, Danielson KG, Hall DJ, Tuan RS (2005a) A three-dimensional nanofibrous scaffold for cartilage tissue engineering using human mesenchymal stem cells. Biomaterials 26: 599-609.

Li Z, Ramay HR, Hauch KD, Xiao D, Zhang M (2005b) Chitosan-alginate hybrid scaffolds for bone tissue engineering. Biomaterials 26: 3919-3928.

Li Z, Gunn J, Chen MH, Cooper A, Zhang M (2008) On-site alginate gelation for enhanced cell proliferation and uniform distribution in porous scaffolds. J Biomed Mater Res A 86: 552-559.

Li Z, Kaplan KM, Wertzel A, Peroglio M, Amit B, Alini M, Grad S, Yayon A (2014) Biomimetic fibrin-hyaluronan hydrogels for nucleus pulposus regeneration. Regen Med 9: 309-326.

Liang CZ, Li H, Tao YQ, Zhou XP, Yang ZR, Xiao YX, Li FC, Han B, Chen QX (2012) Dual delivery for stem cell differentiation using dexamethasone and bFGF in/on polymeric microspheres as a cell carrier for nucleus pulposus regeneration. J Mater Sci Med 23: 1097-1107.

Liang CZ, Li H, Tao YQ, Peng LH, Gao JQ, Wu JJ, Li FC, Hua JM, Chen QX (2013) Dual release of dexamethasone and TGF-beta3 from polymeric microspheres for stem cell matrix accumulation in a rat disc degeneration model. Acta Biomater 9: 9423-9433.

Likhitpanichkul M, Dreischarf M, Illien-Junger S, Walter BA, Nukaga T, Long RG, Sakai D, Hecht AC, Iatridis JC (2014) Fibrin-genipin adhesive hydrogel for annulus fibrosus repair: performance evaluation with large animal organ culture, in situ biomechanics, and in vivo degradation tests. Eur Cell Mater 28: 25-28.

Lin CC, Anseth KS (2009) PEG hydrogels for the controlled release of biomolecules in regenerative medicine. Pharm Res 26: 631-643.

Loeser RF (2014) Integrins and chondrocyte-matrix interactions in articular cartilage. Matrix Biol 39: 11-16.

Loo Y, Zhang S, Hauser CA (2012) From short peptides to nanofibers to macromolecular assemblies in biomedicine. Biotechnol Adv 30: 593-603.

Lopez A, Persson C, Hilborn J, Engqvist H (2010) Synthesis and characterization of injectable composites of poly[D,L-lactide-co-(epsilon-caprolactone)] reinforced with beta-TCP and $\mathrm{CaCO}_{3}$ for intervertebral disk augmentation. J Biomed Mater Res B Appl Biomater 95: 75-83.

Luoma K, Riihimaki H, Luukkonen R, Raininko R, Viikari-Juntura E, Lamminen A (2000) Low back pain in relation to lumbar disc degeneration. Spine 25: 487-492. 
Ma K, Titan AL, Stafford M, Zheng CH, Levenston ME (2012) Variations in chondrogenesis of human bone marrow-deriv ed mesenchymal stem cells in fibrin/alginate blended hydrogels. Acta Biomater 8: 3754-3764.

Malhotra NR, Han WM, Beckstein J, Cloyd J, Chen W, Elliott DM (2012) An injectable nucleus pulposus implant restores compressive range of motion in the ovine disc. Spine 37: E1099-1105.

Mao JS, Cui YL, Wang XH, Sun Y, Yin YJ, Zhao HM, De Yao K (2004) A preliminary study on chitosan and gelatin polyelectrolyte complex cytocompatibility by cell cycle and apoptosis analysis. Biomaterials 25: 3973-3981.

Martin MD, Boxell CM, Malone DG (2002) Pathophysiology of lumbar disc degeneration: a review of the literature. Neurosurg Focus 13: E1.

Martin JT, Milby AH, Chiaro JA, Kim DH, Hebela NM, Smith LJ, Elliott DM, Mauck RL (2014) Translation of an engineered nanofibrous disc-like angle-ply structure for intervertebral disc replacement in a small animal model. Acta Biomater 10: 2473-2481.

Masuda K (2008) Biological repair of the degenerated intervertebral disc by the injection of growth factors. Eur Spine J 17 Suppl 4: 441-451.

Mauth C, Bono E, Haas S, Paesold G, Wiese H, Maier G, Boos N, Graf-Hausner U (2009) Cell-seeded polyurethane-fibrin structures - a possible system for intervertebral disc regeneration. Eur Cell Mater 18: 27-29.

Mayer JE, Iatridis JC, Chan D, Qureshi SA, Gottesman O, Hecht AC (2013) Genetic polymorphisms associated with intervertebral disc degeneration. Spine J 13: 299-317.

McBeath R, Pirone DM, Nelson CM, Bhadriraju K, Chen CS (2004) Cell shape, cytoskeletal tension, and RhoA regulate stem cell lineage commitment. Dev Cell 6: 483-495.

McCann MR, Tamplin OJ, Rossant J, Séguin CA (2012) Tracing notochord-derived cells using a Noto-cre mouse: implications for intervertebral disc development. Dis Model Mech 5: 73-82.

Mehlhorn AT, Zwingmann J, Finkenzeller G, Niemeyer P, Dauner M, Stark B, Südkamp NP, Schmal H (2009) Chondrogenesis of adipose-derived adult stem cells in a poly-lactide-co-glycolide scaffold. Tissue Eng Part A 15: 1159-1167.

Melrose J, Smith S, Ghosh P, Taylor TK (2001) Differential expression of proteoglycan epitopes and growth characteristics of intervertebral disc cells grown in alginate bead culture. Cells Tissues Organs 168: 137-146.

Mercuri J, Addington C, Pascal R, Gill S, Simionescu D (2014) Development and initial characterization of a chemically stabilized elastin-glycosaminoglycan-collagen composite shape-memory hydrogel for nucleus pulposus regeneration. J Biomed Mater Res A 102: 4380-4393.

Miller JA, Schmatz C, Schultz AB (1988) Lumbar disc degeneration: correlation with age, sex, and spine level in 600 autopsy specimens. Spine 13: 173-178.

Mizuno H, Roy AK, Vacanti CA, Kojima K, Ueda M, Bonassar LJ (2004) Tissue-engineered composites of annulus fibrosus and nucleus pulposus for intervertebral disc replacement. Spine 29: 1290-1298.

Nagae M, Ikeda T, Mikami Y, Hase H, Ozawa H, Matsuda K, Sakamoto H, Tabata Y, Kawata M, Kubo T
(2007) Intervertebral disc regeneration using platelet-rich plasma and biodegradable gelatin hydrogel microspheres. Tissue Eng 13: 147-158.

Näkki A, Battié MC, Kaprio J (2014) Genetics of discrelated disorders: current findings and lessons from other complex diseases. Eur Spine J 23 Suppl 3: S354-363.

Neidlinger-Wilke C, Liedert A, Wuertz K, Buser Z, Rinkler C, Käfer W, Ignatius A, Claes L, Roberts S, Johnson WEB (2009) Mechanical stimulation alters pleiotrophin and aggrecan expression by human intervertebral disc cells and influences their capacity to stimulate endothelial cell migration. Spine 34: 663-669.

Nerurkar NL, Sen S, Huang AH, Elliott DM, Mauck RL (2010) Engineered disc-like angle-ply structures for intervertebral disc replacement. Spine 35: 867-873.

Nguyen QT, Hwang Y, Chen AC, Varghese S, Sah RL (2012) Cartilage-like mechanical properties of poly(ethylene glycol)-diacrylate hydrogels. Biomaterials 33: 6682-6690.

Nicodemus GD, Bryant SJ (2008) Cell encapsulation in biodegradable hydrogels for tissue engineering applications. Tissue Eng B Rev 14: 149-165.

Nunamaker EA, Purcell EK, Kipke DR (2007) In vivo stability and biocompatibility of implanted calcium alginate disks. J Biomed Mater Res A 83: 1128-1137.

Oliveira MB, Ribeiro MP, Miguel SP, Neto AI, Coutinho P, Correia IJ, Mano JF (2014) In vivo high-content evaluation of three-dimensional scaffolds biocompatibility. Tissue Eng Part C Methods 20: 851-864.

Park JS, Chu JS, Tsou AD, Diop R, Wang A, Li S (2011a) The effect of matrix stiffness on the differentiation of mesenchymal stem cells in response to TGF- $\beta$. Biomaterials 32: 3921-3930.

Park SH, Cho H, Gil ES, Mandal BB, Min BH, Kaplan DL (2011b) Silk-fibrin/hyaluronic acid composite gels for nucleus pulposus tissue regeneration. Tissue Eng A 17: 2999-3009.

Park S, Gil ES, Mandal BB, Cho HS, Kluge JA, Min B, Kaplan DL, Engineering B, Medford CS (2012) Annulus fibrosus tissue engineering using lamellar silk scaffolds. J Tissue Eng Regen Med 6: s24-s33.

Park H, Gong M-S, Park J-H, Moon S-I, Wall IB, Kim H-W, Lee JH, Knowles JC (2013) Silk fibroin-polyurethane blends: physical properties and effect of silk fibroin content on viscoelasticity, biocompatibility and myoblast differentiation. Acta Biomater 9: 8962-8971.

Patel MP, Patel RR, Patel JK (2010) Chitosan mediated targeted drug delivery system: a review. J Pharm Pharm Sci 13: 536-557.

Pearlstein E, Gold L, Garcia-Pardo A(1980) Fibronectin: a review of its structure and biological activity. Mol Cell Biochem 29: 103-128.

Pereira CL, Gonçalves RM, Peroglio M, Pattappa G, D'Este M, Eglin D, Barbosa MA, Alini M, Grad S (2014) The effect of hyaluronan-based delivery of stromal cell-derived factor- 1 on the recruitment of MSCs in degenerating intervertebral discs. Biomaterials 35: 81448153.

Peroglio M, Grad S, Mortisen D, Sprecher CM, Illien-Junger S, Alini M, Eglin D (2012) Injectable thermoreversible hyaluronan-based hydrogels for nucleus 
pulposus cell encapsulation. Eur Spine J 21 Suppl 6: S839849.

Pirvu T, Blanquer SBG, Benneker LM, Grijpma DW, Richards RG, Alini M, Eglin D, Grad S, Li Z (2015) A combined biomaterial and cellular approach for annulus fibrosus rupture repair. Biomaterials 42: 11-19.

Purmessur D, Guterl CC, Cho SK, Cornejo MC, Lam YW, Ballif BA, Laudier DM, Iatridis JC (2013) Dynamic pressurization induces transition of notochordal cells to a mature phenotype while retaining production of important patterning ligands from development. Arthritis Res Ther 15: R122.

Pusateri AE, McCarthy SJ, Gregory KW, Harris RA, Cardenas L, McManus AT, Goodwin Jr CW (2003) Effect of a chitosan-based hemostatic dressing on blood loss and survival in a model of severe venous hemorrhage and hepatic injury in swine. J Trauma 54: 177-182.

Radcliff KE, Kepler CK, Jakoi A, Sidhu GS, Rihn J, Vaccaro AR, Albert TJ, Hilibrand AS (2013) Adjacent segment disease in the lumbar spine following different treatment interventions. Spine J 13: 1339-1349.

Raeber GP, Lutolf MP, Hubbell JA (2005) Molecularly engineered PEG hydrogels: a novel model system for proteolytically mediated cell migration. Biophys J 89: 1374-1388.

Re'em T, Tsur-Gang O, Cohen S (2010) The effect of immobilized RGD peptide in macroporous alginate scaffolds on TGFbeta1-induced chondrogenesis of human mesenchymal stem cells. Biomaterials 31: 6746-6755.

Richardson SM, Hoyland JA (2008) Stem cell regeneration of degenerated intervertebral discs: current status. Curr Pain Headache Rep 12: 83-88.

Richardson SM, Hughes N, Hunt JA, Freemont AJ, Hoyland JA (2008) Human mesenchymal stem cell differentiation to NP-like cells in chitosan-glycerophosphate hydrogels. Biomaterials 29: 85-93.

Risbud MV, Guttapalli A, Tsai T-T, Lee JY, Danielson KG, Vaccaro AR, Albert TJ, Gazit Z, Gazit D, Shapiro IM (2007) Evidence for skeletal progenitor cells in the degenerate human intervertebral disc. Spine 32: 2537 2544.

Risbud MV, Schoepflin ZR, Mwale F, Kandel R, Grad S, Iatridis JC, Sakai D, Hoyland J (2015) Defining the phenotype of young healthy nucleus pulposus cells: recommendations of the Spine Research Interest Group at the 2014 Annual ORS Meeting. J Orthop Res 33: 283-293.

Roughley P, Hoemann C, DesRosiers E, Mwale F, Antoniou J, Alini M (2006) The potential of chitosanbased gels containing intervertebral disc cells for nucleus pulposus supplementation. Biomaterials 27: 388-396.

Ruan DK, Xin H, Zhang C, Wang C, Xu C, Li C, He Q (2010) Experimental intervertebral disc regeneration with tissue-engineered composite in a canine model. Tissue Eng A 16: 2381-2389.

Sakai D, Nakamura Y, Nakai T, Mishima T, Kato S, Grad S, Alini M, Risbud MV, Chan D, Cheah KSE, Yamamura K, Masuda K, Okano H, Ando K, Mochida J (2012) Exhaustion of nucleus pulposus progenitor cells with ageing and degeneration of the intervertebral disc. Nat Commun 3: 1264.
Santerre JP, Woodhouse K, Laroche G, Labow RS (2005) Understanding the biodegradation of polyurethanes: from classical implants to tissue engineering materials. Biomaterials 26: 7457-7470.

Sasson A, Patchornik S, Eliasy R, Robinson D, Haj-Ali R (2012) Hyperelastic mechanical behavior of chitosan hydrogels for nucleus pulposus replacement - experimental testing and constitutive modeling. J Mech Behav Biomed Mater 8: 143-153.

Sawamura K, Ikeda T, Nagae M, Okamoto S, Mikami Y, Hase H, Ikoma K, Yamada T, Sakamoto H, Matsuda K, Tabata Y, Kawata M, Kubo T (2009) Characterization of in vivo effects of platelet-rich plasma and biodegradable gelatin hydrogel microspheres on degenerated intervertebral discs. Tissue Eng A 15: 3719-3727.

Schek RM, Michalek AJ, Iatridis JC (2011) Genipincrosslinked fibrin hydrogels as a potential adhesive to augment intervertebral disc annulus repair. Eur Cell Mater 21: 373-383.

Scholz B, Kinzelmann C, Benz K, Mollenhauer J, Wurst H, Schlosshauer B (2010) Suppression of adverse angiogenesis in an albumin-based hydrogel for articular cartilage and intervertebral disc regeneration. Eur Cell Mater 20: 24-27.

Setton LA, Chen J (2006) Mechanobiology of the intervertebral disc and relevance to disc degeneration. $\mathrm{J}$ Bone Joint Surg Am 88 Suppl 2 52-57.

Shao X, Hunter CJ (2007) Developing an alginate/ chitosan hybrid fiber scaffold for annulus fibrosus cells. J Biomed Mater Res A 82: 701-710.

Sharma MB, Limaye LS, Kale VP (2012) Mimicking the functional hematopoietic stem cell niche in vitro: recapitulation of marrow physiology by hydrogel-based three-dimensional cultures of mesenchymal stromal cells. Haematologica 97: 651-660.

Shokouhi B, Coban C, Hasirci V, Aydin E, Dhanasingh A, Shi N, Koyama S, Akira S, Zenke M, Sechi AS (2010) The role of multiple toll-like receptor signalling cascades on interactions between biomedical polymers and dendritic cells. Biomaterials 31: 5759-5771.

Sillat T, Barreto G, Clarijs P, Soininen A, Ainola M, Pajarinen J, Korhonen M, Konttinen YT, Sakalyte R, Hukkanen M, Ylinen P, Nordström DCE (2013) Tolllike receptors in human chondrocytes and osteoarthritic cartilage. Acta Orthop 84: 585-592.

Silva GA, Ducheyne P, Reis RL (2007) Materials in particulate form for tissue engineering. 1. Basic concepts. J Tissue Eng Regen Med 1: 4-24.

Sinha VR, Bansal K, Kaushik R, Kumria R, Trehan A (2004) Poly-epsilon-caprolactone microspheres and nanospheres: an overview. Int J Pharm 278: 1-23.

Smith LJ, Gorth DJ, Showalter BL, Chiaro JA, Beattie EE, Elliott DM, Mauck RL, Chen W, Malhotra NR (2014) In vitro characterization of a stem-cell-seeded triple-interpenetrating-network hydrogel for functional regeneration of the nucleus pulposus. Tissue Eng Part A 20:1841-1849.

Stern S, Lindenhayn K, Schultz O, Perka C (2000) Cultivation of porcine cells from the nucleus pulposus in a fibrin/hyaluronic acid matrix. Acta Orthop Scand 71: 496-502. 
Stern S, Lindenhayn K, Perka C (2004) Human intervertebral disc cell culture for disc disorders. Clin Orthop Relat Res 419: 238-244.

Strange DG, Oyen ML (2012) Composite hydrogels for nucleus pulposus tissue engineering. J Mech Behav Biomed Mater 11: 16-26.

Su WY, Chen YC, Lin FH (2010) Injectable oxidized hyaluronic acid/adipic acid dihydrazide hydrogel for nucleus pulposus regeneration. Acta Biomater 6: $3044-$ 3055 .

Sun W, Zhang K, Liu G, Ding W, Zhao C, Xie Y, Yuan J, Sun X, Li H, Liu C, Tang T, Zhao J (2014) Sox9 gene transfer enhanced regenerative effect of bone marrow mesenchymal stem cells on the degenerated intervertebral disc in a rabbit model. PLoS One 9: e93570.

Sung HW, Huang RN, Huang LL, Tsai CC (1999) In vitro evaluation of cytotoxicity of a naturally occurring cross-linking reagent for biological tissue fixation. J Biomater Sci Polym Ed 10: 63-78.

Tabata Y, Hijikata S, Muniruzzaman M, Ikada Y (1999) Neovascularization effect of biodegradable gelatin microspheres incorporating basic fibroblast growth factor. J Biomater Sci Polym Ed 10: 79-94.

Tan B, Wei RQ, Tan MY, Luo JC, Deng L, Chen XH, Hou JL, Li XQ, Yang ZM, Xie HQ (2012) Tissue engineered esophagus by mesenchymal stem cell seeding for esophageal repair in a canine model. J Surg Res 182: 40-48.

Tao H, Zhang Y, Wang C-F, Zhang C, Wang X-M, Wang D-L, Bai X-D, Wen T-Y, Xin H-K, Wu J-H, Liu Y, He Q, Ruan D (2014) Biological evaluation of human degenerated nucleus pulposus cells in functionalized selfassembling peptide nanofiber hydrogel scaffold. Tissue Eng Part A 20: 1621-1631.

Thavaneswaran P, Vandepeer M (2014) Lumbar artificial intervertebral disc replacement: a systematic review. ANZ J Surg 84: 121-127.

Tilwani RK, Bader DL, Chowdhury TT (2012) Biomechanical conditioning enhanced matrix synthesis in nucleus pulposus cells cultured in agarose constructs with TGF $\beta$. J Funct Biomater 3: 23-36.

Tiwari A, Salacinski H, Seifalian AM, Hamilton G (2002) New prostheses for use in bypass grafts with special emphasis on polyurethanes. Cardiovasc Surg 10: 191-197.

Trappmann B, Gautrot JE, Connelly JT, Strange DGT, Li Y, Oyen ML, Cohen Stuart MA, Boehm H, Li B, Vogel V, Spatz JP, Watt FM, Huck WTS (2012) Extracellular-matrix tethering regulates stem-cell fate. Nat Mater 11: 642-649.

Trout JJ, Buckwalter JA, Moore KC (1982) Ultrastructure of the human intervertebral disc: II. Cells of the nucleus pulposus. Anat Rec 204: 307-314.

Tsuchida A, Bekkers J, Beekhuizen M, Vonk L, Dhert W, Saris D, Creemers L (2013) Pronounced biomaterial dependency in cartilage regeneration using nonexpanded compared with expanded chondrocytes. Regen Med 8: 583-595.

Tweedie C A Anderson DG, Langer R, Van Vliet KJ. (2005). Combinatorial material mechanics: highthroughput polymer synthesis and nanomechanical screening. Adv Mater 17: 2599-2604.
Urban JP, Roberts S (2003) Degeneration of the intervertebral disc. Arthritis Res Ther 5: 120-130.

Urban JPG, Holm S, Maroudas A, Nachemson A (1977) Nutrition of the intervertebral disk. Clin Orthop Relat Res 129: 101-114.

Van der Veen AJ, van Dieën JH, Nadort A, Stam B, Smit TH (2007) Intervertebral disc recovery after dynamic or static loading in vitro: is there a role for the endplate? J Biomech 40: 2230-2235.

Van Tienen TG, Hannink G, Buma P (2009) Meniscus replacement using synthetic materials. Clin Sports Med 28: 143-156.

Wang L, Stegemann JP (2010) Thermogelling chitosan and collagen composite hydrogels initiated with betaglycerophosphate for bone tissue engineering. Biomaterials 31: 3976-3985.

Wang Y, Kim U-J, Blasioli DJ, Kim H-J, Kaplan DL (2005) In vitro cartilage tissue engineering with 3D porous aqueous-derived silk scaffolds and mesenchymal stem cells. Biomaterials 26: 7082-7094.

Wang B, Wu Y, Shao Z, Yang S, Che B, Sun C, Ma Z, Zhang Y (2012) Functionalized self-assembling peptide nanofiber hydrogel as a scaffold for rabbit nucleus pulposus cells. J Biomed Mater Res A 100: 646-653.

Wang H, Zhou Y, Huang B, Liu L-T, Liu M-H, Wang J, Li C-Q, Zhang Z-F, Chu T-W, Xiong C-J (2014) Utilization of stem cells in alginate for nucleus pulposus tissue engineering. Tissue Eng Part A 20: 908-920.

Wilke HJ, Heuer F, Neidlinger-Wilke C, Claes L (2006) Is a collagen scaffold for a tissue engineered nucleus replacement capable of restoring disc height and stability in an animal model? Eur Spine J 15 Suppl 3: S433-438.

Willems N, Yang HY, Langelaan ML, Tellegen AR, Grinwis GC, Kranenburg HJ, Riemers FM, Plomp SG, Craenmehr EG, Dhert WJ, Papen-Botterhuis NE, Meij BP, Creemers LB, Tryfonidou MA (2015) Biocompatibility and intradiscal application of a thermoreversible celecoxibloaded poly-N-isopropylacrylamide $\mathrm{MgFe}$-layered double hydroxide hydrogel in a canine model. Arthritis Res Ther 17: 214

Williams FM, Bansal AT, van Meurs JB, Bell JT, Meulenbelt I, Suri P, Rivadeneira F, Sambrook PN, Hofman A, Bierma-Zeinstra S, Menni C, Kloppenburg M, Slagboom PE, Hunter DJ, Macgregor AJ, Uitterlinden AG, Spector TD (2012) Novel genetic variants associated with lumbar disc degeneration in northern Europeans: a metaanalysis of 4600 subjects. Ann Rheum Dis 72: 1141-1148.

Wu S-C, Chen C-H, Chang J-K, Fu Y-C, Wang C-K, Eswaramoorthy R, Lin Y-S, Wang Y-H, Lin S-Y, Wang G-J, Ho M-L (2013) Hyaluronan initiates chondrogenesis mainly via CD44 in human adipose-derived stem cells. J Appl Physiol 114: 1610-1618.

$\mathrm{Xu}$ T, Binder KW, Albanna MZ, Dice D, Zhao W, Yoo JJ, Atala A (2012) Hybrid printing of mechanically and biologically improved constructs for cartilage tissue engineering applications. Biofabrication 5: 15001.

Xu L, Wang Q, Xu F, Ye Z, Zhou Y, Tan W-S (2013) Mesenchymal stem cells downregulate articular chondrocyte differentiation in noncontact coculture systems: implications in cartilage tissue regeneration. Stem Cells Dev 22: 1657-1669. 
Xu B, Ju Y, Song G (2014) Role of p38, ERK1/2, focal adhesion kinase, RhoA/ROCK and cytoskeleton in the adipogenesis of human mesenchymal stem cells. J Biosci Bioeng 117: 624-631.

Yan J, Yang S, Sun H, Guo D, Wu B, Ji F, Zhou D (2013) Effects of releasing recombinant human growth and differentiation factor-5 from poly(lactic-co-glycolic acid) microspheres for repair of the rat degenerated intervertebral disc. J Biomater Appl 29: 72-80.

Yang X, Li X (2009) Nucleus pulposus tissue engineering: a brief review. Eur Spine J 18: 1564-1572.

Yang L, Kandel RA, Chang G, Santerre JP (2009) Polar surface chemistry of nanofibrous polyurethane scaffold affects annulus fibrosus cell attachment and early matrix accumulation. J Biomed Mater Res A 91: 1089-1099.

Yang JJ, Chen YM, Liu JF, Kurokawa T, Gong JP (2010) Spontaneous redifferentiation of dedifferentiated human articular chondrocytes on hydrogel surfaces. Tissue Eng Part A 16: 2529-2540.

Yang D, Lü X, Hong Y, Xi T, Zhang D (2013) The molecular mechanism of mediation of adsorbed serum proteins to endothelial cells adhesion and growth on biomaterials. Biomaterials 34: 5747-5758.

Yeganegi M, Kandel RA, Santerre JP (2010) Characterization of a biodegradable electrospun polyurethane nanofiber scaffold: Mechanical properties and cytotoxicity. Acta Biomater 6: 3847-3855.

Yim RL-H, Lee JT-Y, Bow CH, Meij B, Leung V, Cheung KMC, Vavken P, Samartzis D (2014) A systematic review of the safety and efficacy of mesenchymal stem cells for disc degeneration: insights and future directions for regenerative therapeutics. Stem Cells Dev 23: 2553-2567.

Zeng C, Yang Q, Zhu M, Du L, Zhang J, Ma X, Xu B, Wang L (2014) Silk fibroin porous scaffolds for nucleus pulposus tissue engineering. Mater Sci Eng C Mater Biol Appl 37: 232-240.

Zhang L-M, Wu C-X, Huang J-Y, Peng X-H, Chen P, Tang S-Q (2012) Synthesis and characterization of a degradable composite agarose/HA hydrogel. Carbohydr Polym 88: 1445-1452.

Zhang Z, Li F, Tian H, Guan K, Zhao G, Shan J, Ren D (2014) Differentiation of adipose-derived stem cells toward nucleus pulposus-like cells induced by hypoxia and a three-dimensional chitosan-alginate gel scaffold in vitro. Chin Med J (Engl) 127: 314-321.

Zhu J (2010) Bioactive modification of poly(ethylene glycol) hydrogels for tissue engineering. Biomaterials 31: 4639-4656.

\section{Web Reference}

1. http://clinicaltrials.gov/show/NCT01640457 [18-112014]

\section{Discussion with Reviewers}

Reviewer I: I would agree with the authors that the ability to perform in vitro high throughput screening of biomaterials is required to improve on their selection for use in IVD repair strategy. However, could the authors briefly discuss what are in their opinion the "minimum" and specific ex vivo quantitative outcome parameters that should be collected to select the most suitable stiffness or tensile strength close to IVD tissues, EC matrix accumulation / composition, etc.?

Authors: High throughput screening is usually based on readout parameters that are easy to measure, often gene expression-based detection systems employing luciferase or GFP. To this end, simple detection of collagen II and aggrecan expression with as negative markers collagen $\mathrm{X}$ and collagen I (for the NP) would be useful. The use of medium throughput assays that can measure these genes at the protein level, aiming for the healthy tissues' ratios of their respective ECM proteins, at least including collagen II, I and aggrecan, could be the next step. Ideally, medium to low throughput systems will be developed that can subsequently measure biomechanical properties of mature biomaterial-cell constructs. Those characterising NP tissue, i.e. elastic and shear modulus, and the AF, tensile strength and compressive modulus, would predict functionality and thus be helpful in final selection of materials for more extensive experiments, including in vivo models of disease.

Reviewer II: The authors note the need for a 'standard' or reference material for comparison studies to be made. The same might also true for a standard media composition and oxygen environment. What would these authors suggest for the field in terms of reference materials and environments by which to compare new materials?

Authors: Although it is tempting to specify a few particular biomaterials, first several studies by independent research groups should be performed comparing the currently most often used biomaterials, be they synthetic or natural. The current review will be helpful at providing some suggestions for candidate materials. Those materials that consistently show most regenerative properties in terms of extensive NP-like matrix formation at the protein level, preferably under relevant biomechanical loads, may subsequently be used as reference materials. Any new materials that, in the future, consistently show to have more regenerative properties than the original materials, may be added to or replace the original set of reference materials. For culture conditions, it will be less easy to define optimal conditions. Ideally, the environment of the (human) degenerated IVD is mimicked, but even to the extent that this environment has been characterised, the importance of and mechanisms behind these characteristics (e.g. hypoxia, glucose content) is still not completely elucidated. Moreover, these characteristics may only be relevant if they affect the direction of the response to the biomaterial. This would need to be determined first, for example using the abovementioned reference materials.

Editor's Note: Scientific Editor in charge of the paper: Brian Johnstone. 